\title{
THE POSSIBILITIES OF SPATIAL ANALYSIS OF GRAVE POTTERY ON THE EXAMPLE OF LA TÈNE CEMETERY IN MALÉ KOSIHY ${ }^{1}$
}

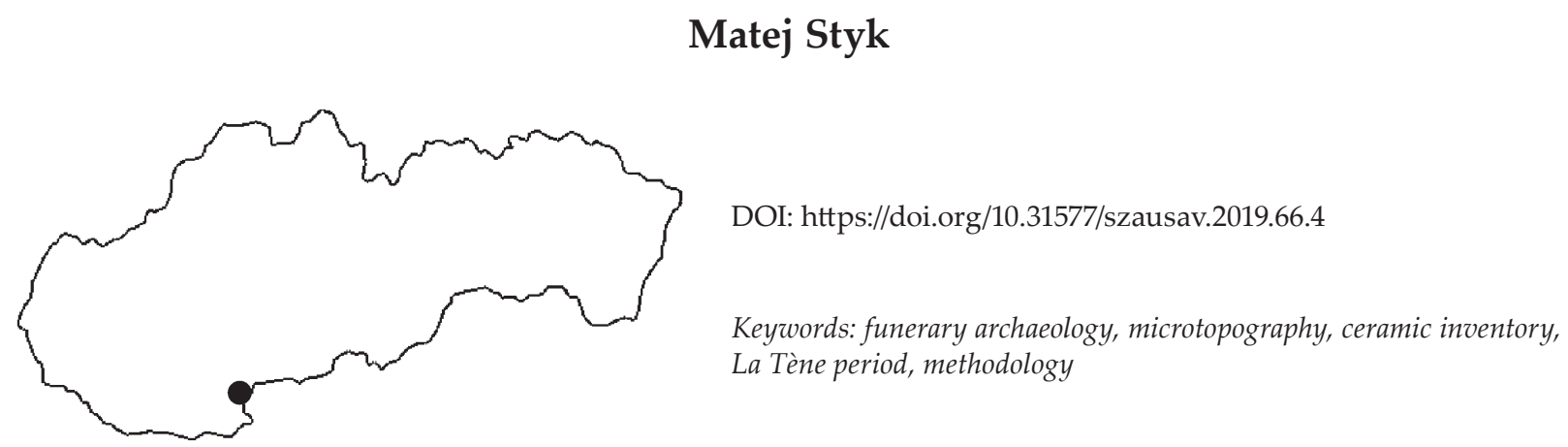

The paper deals with the study of ceramic inventory in La Tène graves. It brings insight into the function of these grave goods not only through the assessment of the spatial relationship of pottery and human remains but also the combination of individual vessel types. Usage of microtopography method, combines the spatial and qualitative attributes of individual vessels. On the example of the cemetery in Malé Kosihy, we present the advantages and pitfalls of this method as well as possible interpretative levels. At the end of the paper, the presented procedure is confronted with other approaches to the interpretation of the function of vessels in the grave inventory.

\section{INTRODUCTION}

Pottery is the most common component of grave goods, but despite this fact, only marginal attention has been paid to its role at burial rite in modern studies. Funerary archaeology understands the burial rite comprehensively and, thus, works with human remains as well as with the form and arrangement of graves and relevant inventory. The aim of the article is to point to the importance of the space itself and the structure of the ceramic goods in the burial rite. Although it is aware of considerable limitations of the interpretation of phenomena such as identity or social status of the buried individual (see Brück 2006, 73-101), it respects the relevance of ceramic corporal grave goods in the process of funeral ceremonies and attempts to define their role in the burial rite. The goal is to present a suitable method for solving combinations of vessels in relation to other variables such as space and other elements of the burial rite. It is based on a principle called microtopography of grave goods. Regarding the quantitative conditionality of the interpretation logic, the emphasis is put on the sufficient extent of the source base. Thus, the article includes a case study at the La Tène cemetery in Malé Kosihy (Nové Zámky district), where a theoretical model of variability of the burial rite by means of disposal of ceramic goods is assessed.

\section{BACKGROUND}

The long-term interest in the study of funerary pottery has brought numerous results; several contributions have dealt with this topic in the domestic environment (Fusek 2005, 5). Although the variability of the ceramic goods is being reconsidered in newer works (e. g. D ud'áková 2014, 487-492), the theoretical basis still relies on observing of the structure. At monitoring of the specific deposition of vessels, more attention is paid to selected types of pottery shapes (Krekovič 2007, 113-116; Müller 2012, 343-364; Repka $2017,207-221)$. We come across analysis of spatial distribution of corporal grave goods more often in foreign literature (Kovářová 2004, 23-37; Sørensen/Rebay 2005, 153-175). There is also an attempt to interpret the social structure by means of qualitative characteristics of vessels (e. g. Krištuf 2005, 69-118). Study of

1 This study was supported by research project 1/0680/16 of the Scientific Grant Agency VEGA of the Slovak Republic and UGA I/8/2019. 
the vessels' function in the burial rite is important; we can observe qualities of individual vessels and their relation to the deceased (Repka 2018, 239-259; Rusu-Bolindet 2014, 240-242; Sørensen/Rebay 2008, 49-74). Works dealing with the study of regional differences by means of the analysis of specific vessels, for instance, urns (Oestigaard 1999, 345-364), are rare. The last but not least, detailed analysis of pottery shapes is used to solve chronological problems (Demján 2012, 77-93; Reinhold 1996, 195-202).

In this topic, there is a separate approach dealing with the microtopography of grave goods. Most frequently, it uses basic spatial method for classification of the position of artefacts by means of schematic quantification (Buchvaldek/Koutecký 1972, 142-179). It is followed by a procedure dividing each grave into individual sectors on the bottom level (Neustupný/Smrž 1989, 282, 383), another type of division defines sectors in association with the body and the location as well as shape of the sectors is directly dependent on the position of the body. These are extended by a method using coordinate systems (e. g. Demján 2012, 81). A different approach defined location of corporal grave goods in relation to social symbolism, i. e. regarding specific body parts of the buried (Kaňáková/Parma 2015, 515-546).

\section{THEORETICAL FRAMEWORK}

The basic methodological element of the submitted study is schematized assessment of the burial rite by means of the so-called Linked analytical process (LAP). I have published its detailed definition separately (Styk 2019, 169-185) and here, I am just going to sum up its most important points. The LAP approach divides the whole topic of the burial rite into three levels of research.

- Basic unit - defines a complex of finds corresponding with a burial feature in general, a disposal feature in particular, mostly a grave.

- Structure - defines a unit correspondent in general with a burial area, a cemetery in particular.

- Complex - defines the cultural landscape, i. e. the whole cultural space depicting the relation between the burial and settlement areas and topographic elements.

Creation of a hierarchized procedure of analysis and synthesis applied to a burial context from the analysis of a Basic unit through the analysis of a Structure to the assessment of a Complex is the main principle of the LAP. Thus, in the presented topic, these are the methods dealing with the analysis of a burial feature, analysis of a cemetery and then the analysis of the cultural landscape. This procedure uses individual methods as partial steps or tools for achieving partial results. As for the LAP, the aggregate of the Basic unit or the aggregate of the Structure or the Complex is independent research space. Thus, based on the division of the archaeological method into the analysis, synthesis and interpretation (see Neustupny 2007, 76), the steps of analysis and synthesis can be associated with all three LAP levels; in each, they are separate procedures which hierarchically follow from each other. The hypothesis assumes that interpretation of the studied phenomena can be done as late as the level of Structure; however, within the valid procedure, it can be done after the synthesis of the Complex. This means that the interpretation of the studied phenomena must be preceded by synthesis of the Basic unit (if possible), Structure and Complex. The presented sequence describes an assumed state and creates a basic framework of research whose specific features change according to the questions and input data of research.

In my spatial study of the ceramic inventory, I follow from the theoretical model describing the problem of studying the development of burials (see Styk 2019, 175-177). It presents the basic question of the study of the burial rite including time and funerary practices. It follows from identification of three important elements - variability of the burial rite, relative chronology and temporal variation of the burial rite (Fig. 1). According to the set model, the variability of the burial rite corresponds with the study of a wide range of attributes associated with a burial feature. It deals with three main points:

a) grave arrangement,

b) the spatial relation of inventory and human remains,

c) location and condition of human remains.

Study of spatial relations of corporal grave goods and other objects in the funerary context ${ }^{2}$ is crucial for this work. The grave inventory can be classified in accordance with the order and distance

2 The set of elements which have spatial, quantitative and qualitative properites associated with burial features, areas or landscape components. These elements are also related to ritual activities of the past societies associated with funeral and burying of human remains (Styk 2019, 170). 


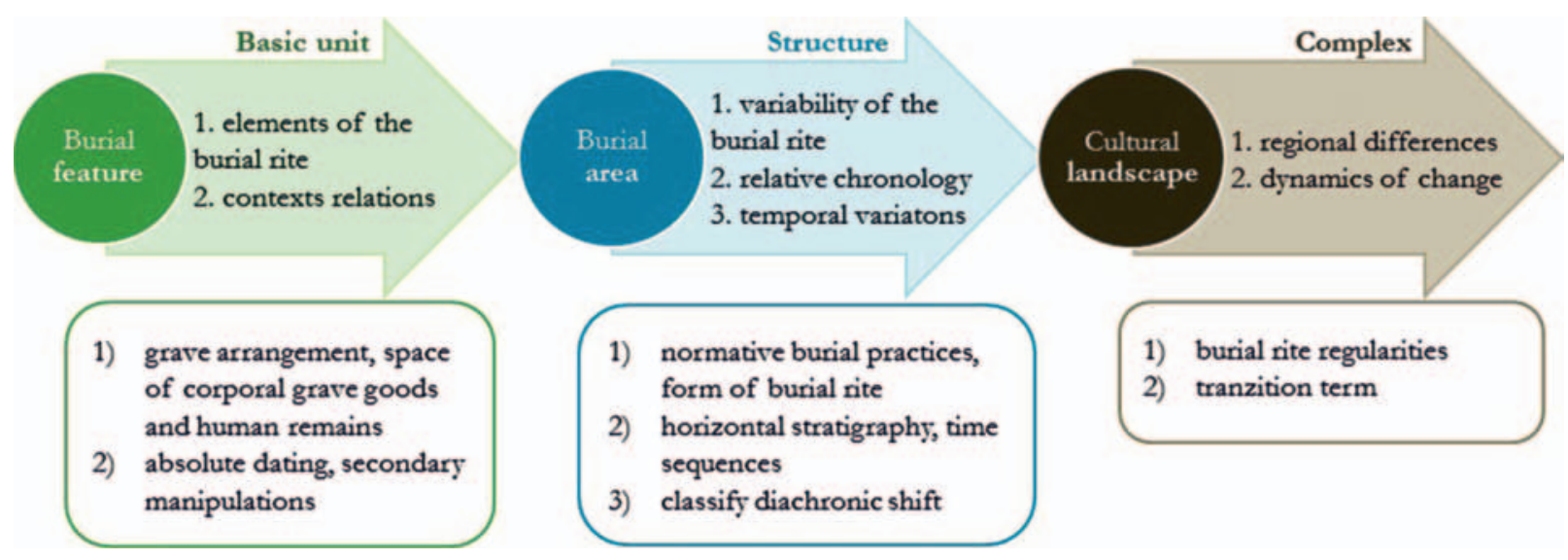

Fig. 1. Scheme of LAP sequence for burying development solution. The arrows show the position of the research points at each LAP level. Rectangles are defined as areas of interest for analysis and synthesis methods.

from the deceased into personal objects (on the body, in contact with the body or associated with the remains), corporal grave goods (deposited in the grave space) and other goods (Arnold 2001, 219). It is the position in relation to human remains which is often solved regarding mutual connections referring to the proximity to certain body parts or integration with cremation remains (Perego 2010, 73). It is also important to monitor the composition of grave goods, types and condition of the objects as well as their qualities. Judging by these attributes, we distinguish between objects associated with funerary practices, corporal grave goods, personal equipment or grave offerings (Härke 2014, 41-60). By means of their arrangement, it is possible to set standards showing the normative burial practices (Siklósi 2007, 186). The arrangement of items also helps us understand the grave disposition. It points out how the grave was entered, also how the given community perceived the spatial arrangement and position of the grave in the cemetery (Rebay-Salisbury 2007, 140). Specific attention is paid to pottery as a frequent type of corporal grave goods. Archaeologists usually distinguish pottery near human remains and distinctly separated pottery creating so-called ceramic sets. In association with burial rituals, the ceramic sets have attributed the function of containers for food and liquids used at burial-feasts (Bujna 1991, 236; Rebay 2003, 290, 291; Valentová/Šumberová 2011, 453-439). Such an assumption is tendentious to some extent and does not take different meaning of pottery in the burial rite into consideration. Identification of the function of the ceramic inventory bears many risks but is also an important step for selection of relevant ceramic collection. It contains vessels functioning as containers for corporal grave goods (possible liquids, food or jewels) which I will call a ceramic set. Besides them, we can distinguish vessels well, representing containers for human remains (urns) and vessels secondarily used as lids. The problem of intentionally broken vessels enters here, extending the interpretation spectrum of the pottery's function in the graves. It was separately dealt with by D. Repka (2018, 239-259). In his work, he monitors a whole spectrum of ritual reasons for destruction/“killing" of pottery from sacrificial and magic-protective functions to various forms of purification rituals related to the body or the grave. It is important to mention that some cases of incomplete or fragmentary vessels can still be evidence of feasting during burial-feasts (Kurtz/Boardmann 1971, 146). Tableware is a problem. In case of broken vessels from tableware, it is assumed that those from settlements are deposited in graves for ritual reasons (Bujna 2014, 303). Graphite pottery in particular, played a symbolic role at the funeral. It occurs in men's as well as women's graves and can refer to symbolic destroying of supplies (Trebsche 2011, 468).

Following the objectives of this article and the quality of the model, parameters of the LAP methodological sequence must be set. It means that the study will focus only on one element of the rite variability, i. e. the spatial relation of the inventory and human remains. Looking at the methodological sequence (Fig. 2), it is obvious that we will operate on the levels of Basic unit and Structure. Selecting exclusively ceramic corporal grave goods, it will be necessary to adopt the whole methodology to the character of the source. On the level of Basic unit, the grave goods (pottery in particular) will be the main object of analysis; on the level of Structure, the burial feature (grave in particular, since we are investigating a cemetery) will be the main object. On the level of Complex, it should be a region, which is represented by 


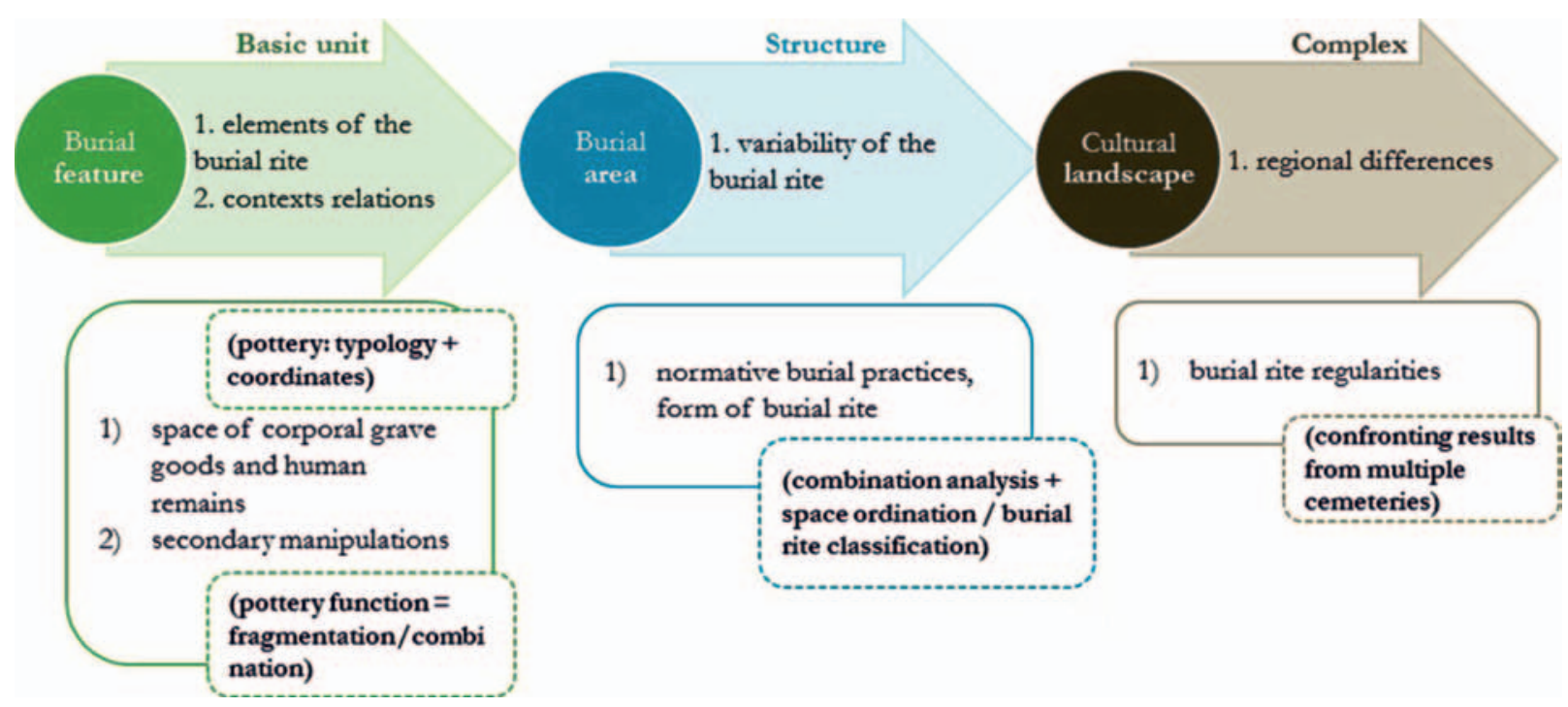

Fig. 2. Scheme of LAP sequence for solution of spatial layout of ceramic inventory. It is based on a modified sequence for development of burying with specified steps in individual steps.

one example in this article (the relation of Ipel' and Žitava river basins). It is logically followed by a set synthesis when we will deal mainly with the procedures defining the variability of the burial rite. This will involve procedures of analysis of the internal arrangement of the grave, qualitative characteristics of artefacts and spatial correlations of the ceramic inventory. Then, regularities in the burial rite will be based on sufficient variables related to the qualities of the burial features and human remains (summarized on the level of Structure in the analysis).

There are several opinions on the technical solution to the spatial variability of pottery in the burial rite. Classification by shapes and frequency is a common approach to the assessment of grave pottery. The number of ceramic individuals at the cemetery per grave is defined, or typological composition of vessels for individual categories of graves (warrior, female, etc.) is set. The question is what the results tell us about the function of the vessels in graves and their position in the burial rite. It is clear that such an approach takes qualitative characteristics of the pottery into consideration only to a limited extent. The relation to the funerary context and mutual relation are obviously absent. At the same time, there is no logical inclusion of space in the funerary context; very often it is not even detected. Thus, it is legitimate to ask how - based on such procedures - it is possible to study the complexity of the burial rite in association with the social and ideological dimension of the funerary practices. A different approach to the analysis of grave pottery is based on microarchaeology and allows detection of secondary information which could be indistinct in common generalization. Not only the spatial relation of pottery and remains but also a combination of individual vessel types itself can bring a more detailed view of the ideological world of the past societies. Extending the method by combination and statistical evaluation aimed at one element of the burial rite will help us better understand the processes associated with the burial as well as processes in the society itself. Detailed solution of the combination of pottery types is absent in the archaeological investigation. Together with the understanding of the importance of space in the burial rite, even old data can bring new results.

\section{DATA}

The cemetery in Malé Kosihy is dated to stages LT B1/B2 - C1b (Bujna 2012a, 1225, 1226). 102 out of 105 researched features were identified as graves. A significant part of the cemetery was investigated (the northern, eastern and southern end), with the exception of the disturbance in the southwestern part. Graves were concentrated mostly in the NE and S parts of the cemetery. 35 inhumation and 63 cremation burials were detected (Bujna 1995, 9-12). 101 graves were included in the database, grave no. 484 was excluded (without human remains and associated goods). As for questionable records, 
cremation burial no. 133 without remains was included as well as graves no. 134, 347, 450 without remains and undetermined rite. Grave no. 11 was - despite presence of a small number of calcinated bones - identified as an inhumation burial of one individual. The disturbed grave no. 283 contained cremation remains deposited in two piles on various levels of the grave pit. By the presence of attributes typical of male (a grindstone and a knife/blade next to remains $\mathrm{B}$ ) and female burials (a hollow anklet/bracelet and a bronze fibula next to remains A), it was identified as a double burial. Presence of numerous corporal grave goods and their diversity in shape and space in individual graves are important information for this study. The question is how specific combinations of individual vessel types are associated with the funerary context and individual elements of the burial rite. Based on the topic of this article, 89 graves out of 101 were selected (containing at least one vessel), in which 285 ceramic individuals were found altogether (Tab. 1: 1. part).

Besides the cemetery in Malé Kosihy, the source base was extended by the cemetery in Maňa for the purpose of some form of verification. The cemetery is located at the site of Hlinisko near the northern periphery of the village, $400 \mathrm{~m}$ from the Žitava river valley. It is dated to stages LT B1-C1 (Bujna 2012b, 1228, 1229). In total, 145 graves - including 109 from the La Tène period - were investigated (Benadik 1983, 7-9). 104 of them were included in the database ${ }^{3}$, graves no. 28a, 45, 46, 48 and 87 were excluded. The category was determined for 94 of the included graves. 101 graves were selected out of 104 (containing at least one vessel), with 271 ceramic individuals found in them (Tab. 2: 1. part).

\section{METHOD}

The principle of this method follows from the fundaments of microarchaeology (Fahlander 2003, 15, 16; Gramsch 2007, 84; Chapman 2000, 69; Kaliff/Oestigaard 2004, 83). Its goal is not to observe the structure (funeral ceremonies) as a whole but to recognize basic mechanisms of individual elements - to be more specific, it means to focus on the form of individual events. By means of this method, the internal arrangement of graves is solved as well as the spatial relation of pottery and human remains, qualitative characteristics of artefacts (pottery), spatial and formal correlation of the ceramic inventory (combinations of vessels).

Classification of shapes of the ceramic inventory and identification of its function is important for the qualitative analysis. To simplify the working process, a common morphological classification of La Tène pottery based on sizes and profiles of vessels was used. In each group, specific varieties on the basis of rim and body profiles were identified. Functions of vessels were identified with a focus on the associated contexts and preservation. From the aspect of preservation, we distinguished additional functions of containers for corporal grave goofs. The original method is aimed to identify intentionally broken pottery by means of the extent of fragmentation and concentration in the area of the grave pit. Incomplete vessels concentrated at several places and isolated fragments are considered to be the crucial indicator (Repka 2018, 240, 241). By this, we can distinguish containers for corporal grave goods (liquids, food, jewels, etc.) and vessels with a different ritual meaning often identified with sacrificial or protective function (Repka 2018, 253, 254). This method tries to identify this group of vessels and separate them from the studied source so that it is possible to work with the ceramic set only.

The space in which the analysis of the ceramic inventory uses processes of microtopography is the common factor for all vessels. This method follows and classifies spatial relations of corporal grave goods and their relations to human remains so that their spatial identification and their relation to the deceased's identity as well as the whole grave context were defined. From the technical point of view, we can monitor the spatial relations by means of various processes - from descriptive nominal attributes associated with the relations to human remains, to the sector method or space quantification. Each of these processes has its advantages and disadvantages, thus, their use always have certain limitations. In first two cases, the relation to the funerary context is clear, which is very useful for interpretation of obtained results, since it is significantly linked with the nature of the studied source. ${ }^{4}$ The technical solution is a problem

3 Included in diploma thesis defended at KARCH Constantine the Philosopher University Nitra (Styk 2015).

4 The ideal combination was presened by the authors at the cemetery of the Únětice culture in Podolí-Pořízný, where they created relative zones which followed from the formal division into sectors but were also related to remains (Kaňákovál Parma 2015, 521, 522). 
since it is rather limited by nominal data and narrows the possibilities of processing of a larger amount of observations and - most of all - of a wider variability of the monitored descriptors. On the other hand, the quantification processes which are based on a certain generalization in the mathematical space cannot link thus created records with the funerary context. It means that it is often problematic to interpret the obtained results in the context of funerary practices. The reason for their use is that they evaluate metric or ordinal data and considerably simplify work with higher numbers of cases and mainly with a wider range of descriptors.

The suggested method is use of the Euclidean space, which could follow from the nature of the funerary context. For simplification (also of the nature of the source), it is possible to work in this phase in a two-dimensional space defined by a Cartesian coordinate system correspondent with bottom of the grave pit. Position of individual vessels will thus be defined in a Cartesian coordinate system by its position on axis $\mathrm{x}$ and $\mathrm{y}$. The change is that this system is more correspondent with the logic of the funerary source than with the strict metric delimitation. It means that metrical relations are more ordinal than relative values since distances of individual coordinates are relativized and adapted so that they could reflect the relation to human remains. It is the position of human remains which defines the space corresponding with one plane of the Euclidean space described by the Cartesian coordinate system (cf. Demján 2012, 81). An important point is that this approach is set identically for inhumation as well as cremation burials, which means that in this study we can follow positions and combinations of ceramic types without crumbling the data source by intentional division of the complex. The Cartesian system is limited by the extent of the $x$-axis $(-3,3)$ and the y-axis $(-5,5)$. The centre of the system is always in the centre of human remains (in two-dimensional space), i. e. in case of inhumation burials, it is in the pelvis area, and in cremation burials, it is in the centre of cremated remains (Fig. 3). As for inhumation remains, the y-axis crosses the median plane of the body, as for cremation remains, it is perpendicular to the walls of the grave pit. Such definition follows from several rules. Position of vessels on the $x$-axis between $(-1,1)$ always corresponds with the direct contact with human remains, in case of cremation remains, it is the same on the y-axis. In case of inhumation remains with the above-mentioned values of the x-axis, the different coordinates of the y-axis can be defined by nominal attributes. ${ }^{5}$ The problem for correct compatibility of inhumation and cremation burials occurs at unification of the funerary context which must respect the real spatial orientation. This problem was solved by rotation of cremation burials in relation to the inhumation ones so that their orientation was uniform (Fig. 4). This results in relativization of spatial observations which is thus associated only with one cemetery. This is, however, sufficient for synthesis on the level of Structure. Each vessel is defined by a spatial description (coordinates of $x$ and y) which also bears information corresponding to the funerary context. It is also defined by the attribute by means of the identified variant of the vessel. Thus, we can follow the spatial relation of the ceramic inventory to the remains, to each other and - at the same time - take its shape (optionally functional) differences into consideration.

The technical solution to this problem was found in statistical analysis, the principal components analysis (PCA) in particular. At the PCA, unlike the factor analysis, the main components follow from a correlation matrix with values on the diagonal, which represents a one-time calculation (see Neustupný 2007, 137). The reason for using the PCA was the need for data reduction into two dimensions to obtain better graphic representation (Shennan 2001,266) as well as the shift of the analysis from simple categorization to more precise monitoring of trends of selected attributes. An important point is that it can work with cardinal and metric data (although some authors assume that it cannot be used for binary data - Siklósi 2013, 51) which logically evaluates the coordinate system. As for nominal data, such as typological range of vessels, transformation by means of absolute values of components in a group was chosen (Chroustovský 2008, 49-60). Calculations were done in PAST software (Hammer 2014, 81).

\section{CASE STUDY}

At the cemetery in Malé Kosihy, there are 101 burials which can be reliably used for the analysis of the burial rite. Pottery occurred only in 89 graves (28 inhumation and 58 cremation graves) represented by at least one individual, which means 285 ceramic individuals in total (Tab. 1: 1. part). At the beginning of

\footnotetext{
5 Values on the $y$-axis: $-4=$ food; $-3=$ calf; $-2=$ knee; $-1=$ thigh; $0=$ pelvis; $1=$ hand; $2=$ elbow; $3=$ arm; $4=$ head.
} 

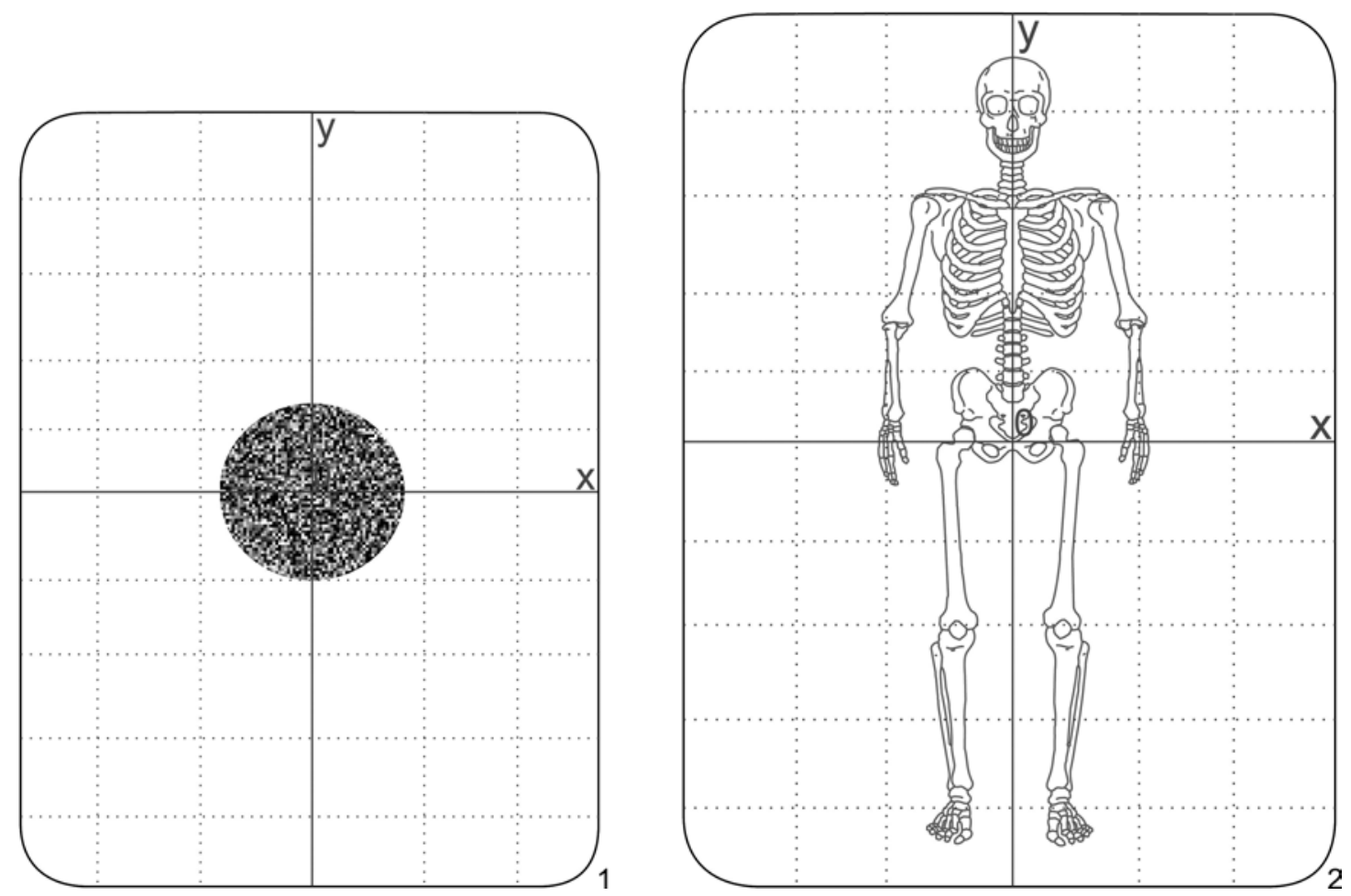

Fig. 3. The use of Cartesian system. Schematic representation of coordinates on grave. 1 - cremation grave; 2 - inhumation grave.
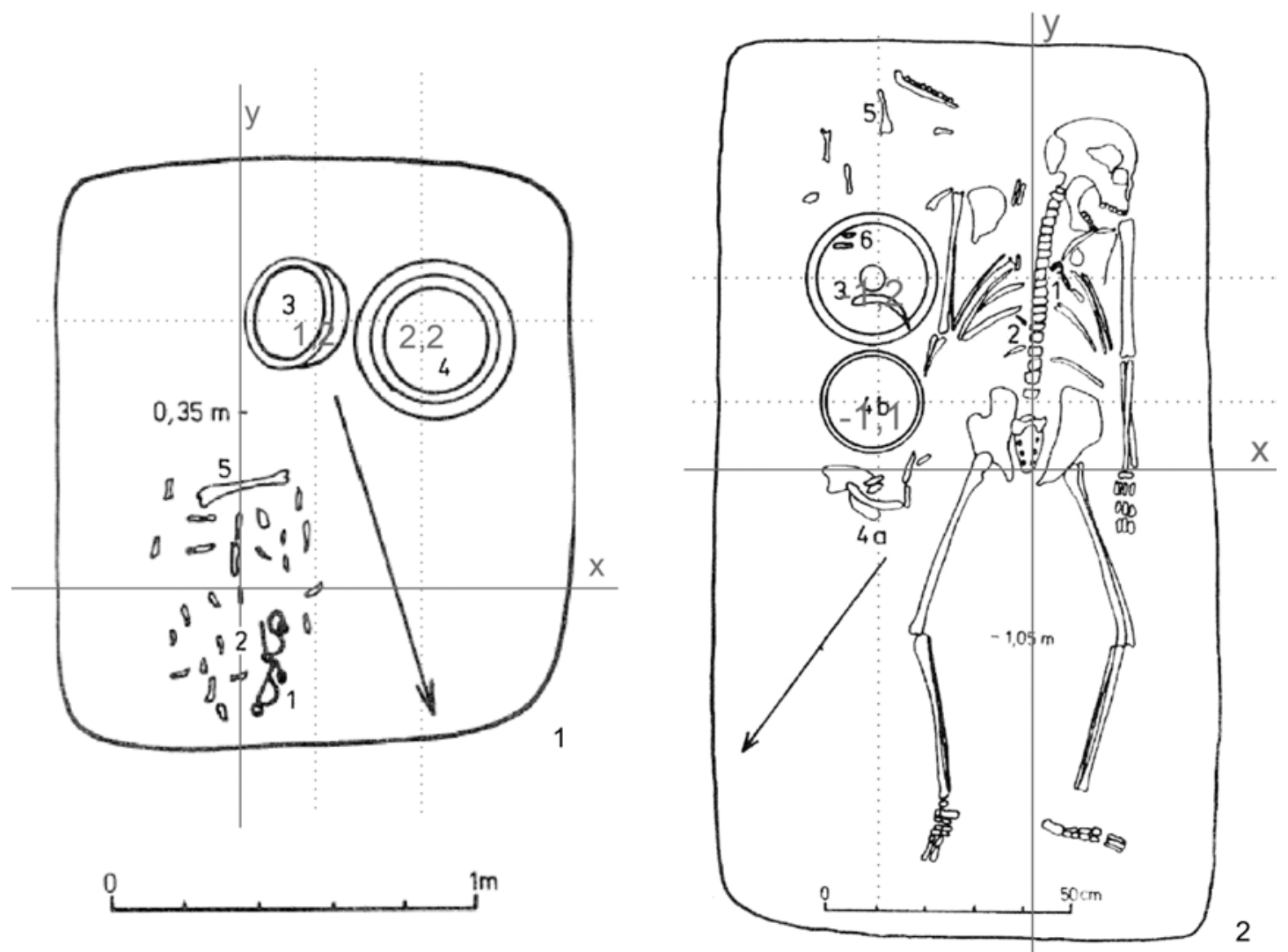

Fig. 4. The use of Cartesian system. 1 - an example of applying the system to cremation grave no. 189 (Bujna 1995, fig. 37); 2 - An example of applying a system to an inhumation grave no. 395 (Bujna 1995, fig. 73b). 


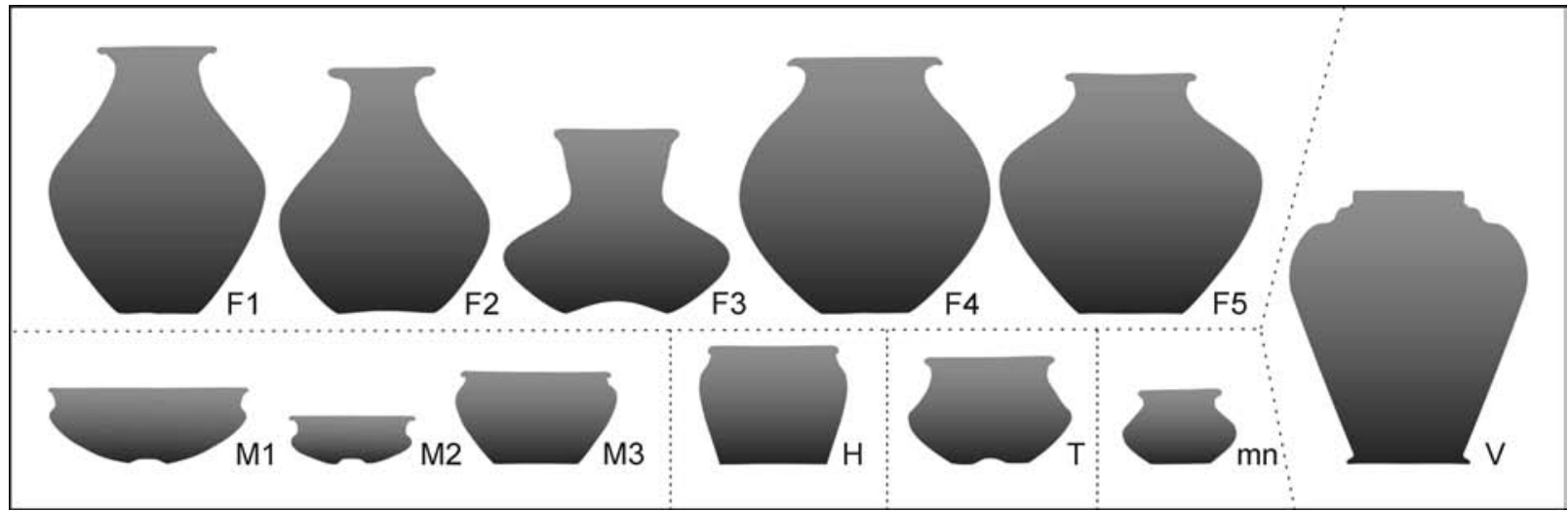

Fig. 5. Ceramic classes and their types based on the analysis of the cemetery Malé Kosihy. F1-5 - bottles; M1-3 - bowl; $\mathrm{T}$ - terrines; $\mathrm{H}$ - pots; $\mathrm{V}$ - vases; $\mathrm{mn}$ - miniature vessels.

the analysis, no selection based on the condition of the grave or the pottery was made so that the source base was not reduced. The procedure is designed to respect the order of the LAP.

The level of Basic unit focuses on the analysis of grave goods (ceramic goods in particular) so that their further evaluation is sufficiently addressed to the funerary context and relations which are apparent in it on the lowest level of the LAP. Quantitative analysis and synthesis of pottery were done to classify ceramic variants and identify their functions. Examined attributes such as size and profiles of vessels were included in the catalogue of the cemetery (Bujna 1995, 14). From the total number of 285 ceramic individuals, 251 individuals were classified (Tab. 1: 2. part). Synthesis correspondent with morphological typology divided the ceramic inventory into six classes, bottles (98 exemplars), pots (16 exemplars), bowls (96 exemplars), terrines (18 exemplars), vases ( 2 exemplars) and miniature vessels (21 exemplars). Miniature vessels did not come out of the morphological classification but were defined by maximum dimensions of 7-11 cm (height and diameter of the rim). Within the group of bottles and bowls, more detailed classification into individual variants (F1-5; M1-3) was possible (Fig. 5).

The next step in the method of microarchaeology was to identify the functions of vessels in the burial rite. The analysis followed from exploring of contextual relations of the pottery which allowed identification of 2 urns, 6 lids and 230 individuals correspondent with a ceramic set. In the framework of ceramic sets, the extent of fragmentation and spatial concentration was examined. Incomplete vessels in several spatial concentrations and isolated fragments were identified as intentionally broken or another ritual function was attributed to them (114 exemplars). Other vessels (116 exemplars) were used as containers for corporal grave goods and were correspondent with ceramic sets (Tab. 1: 3. part).

Analysis of microtopography was the last step. On the level of Basic unit, it was applied to all ceramic individuals. A coordinate was attributed to each vessel based on the above described coordinate system. Thus, 250 individuals were classified (Tab. 1: 3. part - NSC). Regarding the morphological and functional classification, we can work with 209 individuals (Tab. 3 - morf. \& funct. class).

On the level of Structure, categorization of the burial rite should be done according to the preliminary model, which - in our case - is setting the variability of ceramic sets' and typical groups' deposition. These will be later confronted and normed by means of analysis of other elements of the burial rite. This can be obtained by a synthesis of the spatial data following from the microtopography of the ceramic inventory. The goal is to detect significant combinations of the ceramic inventory in graves from the aspect of the range of shapes as well as from the aspect of frequency and spatial distribution. The above-designed process leads to detection of such concentrations which do not evaluate only the spatial but also the qualitative character of the studied artefacts. We can approach the above-mentioned problem in two ways. We can either analyze all vessels regardless of their function or we can study only the containers for corporal grave goods which make the ceramic set and thus can reflect normative burial practices. In the first case, there is the advantage of a wider database but there is also a risk of high variability and interpretation inhomogeneity - Example 1. In the second case, we intentionally interfere with the source, but we obtain more consistent results whose interpretation can be directly related to the preliminary model - Example 2 . 


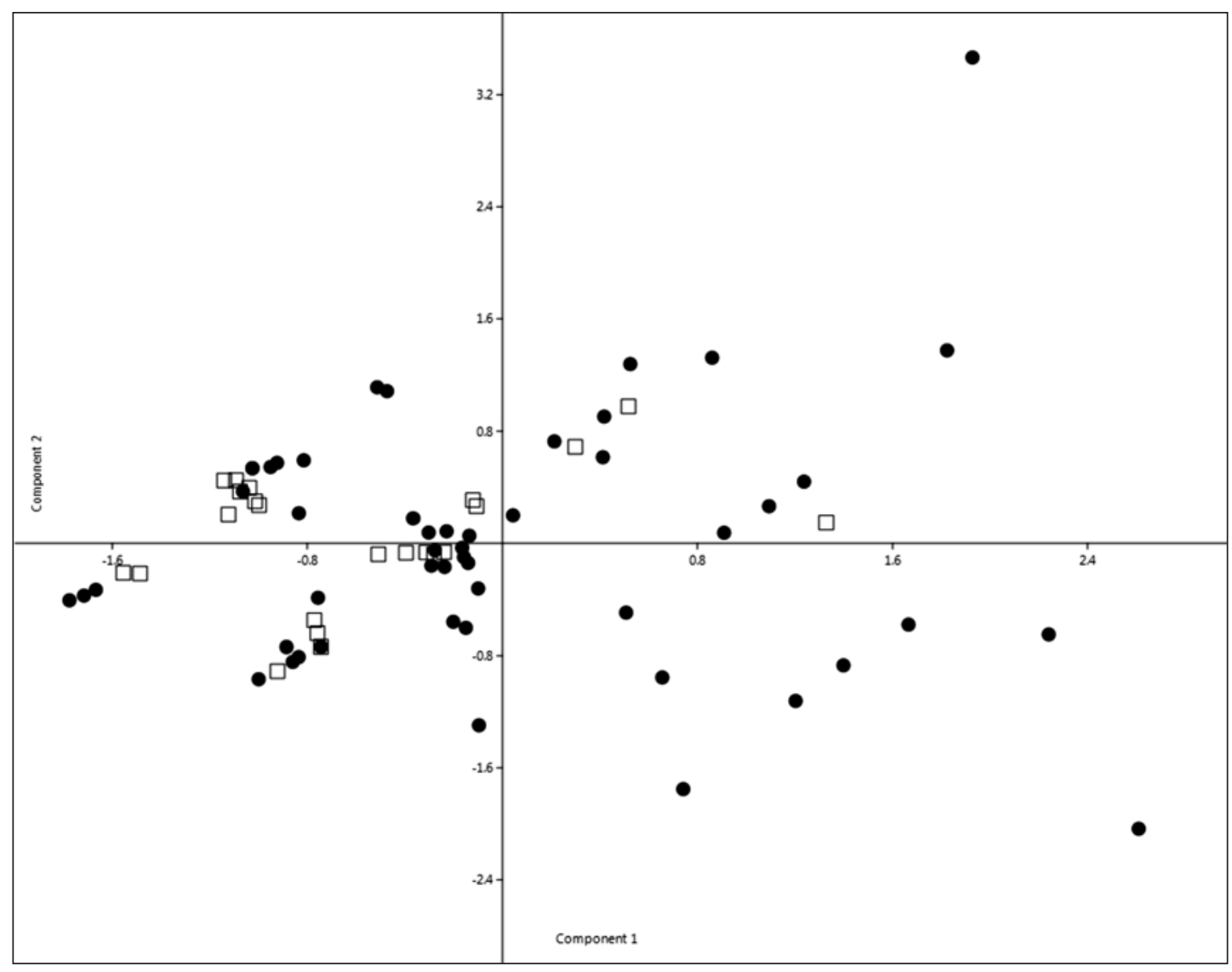

Fig. 6. The resulting PCA analysis plot (Example 1) of a ceramic inventory with undefined function at the cemetery Malé Kosihy. Individual entities (graves) represents the results of spatial and morphological combinations of vessels. Legend: $\square-$ inhumation graves; $\bullet$ - cremation graves.

\section{Example 1}

To obtain the largest base possible, the condition for inclusion was identification of the form of the burial rite, classification of the ceramic type and identification of the relevant sector. From the data matrix, lines and columns with no or single records were filtered out. Thus, 77 graves with 246 ceramic individuals entered the synthesis (Tab. 3: PCA 1). The data matrix consisted of records = burial complexes and attributes = ceramic type (quantity), sector (quantity). In the PCA, the first two components with eigenvalues between 0.6 and 1.6 were significant. The first component defined the combination of a bowl and a bottle in sector $(0,5 ;-1,2)$. The second one described the opposite relation when a bowl appears in sector $(0,2)$ and there was no bottle in the grave. It must be mentioned that the monitored spatial concentrations were always on a low level of importance. Although the total results are obscured by the strong variability, when presented in a diagram and complemented with the data in the form of the burial rite, they describe the following (Fig. 6):

1. we can observe five indistinct groups and a cluster of several outliners defined mainly by different proportions of bowls and bottles;

2. the final diagram bears all traces of abnormal distribution of values of the monitored attributes;

3. in all groups, inhumation, as well as cremation burials, occur.

Great variability in the way of deposition of this type of corporal grave goods is typical but on a certain level of deflection, they can be interconnected. The question is whether such process ignoring the context of the ceramic inventory can evaluate norms of the burial rite. 


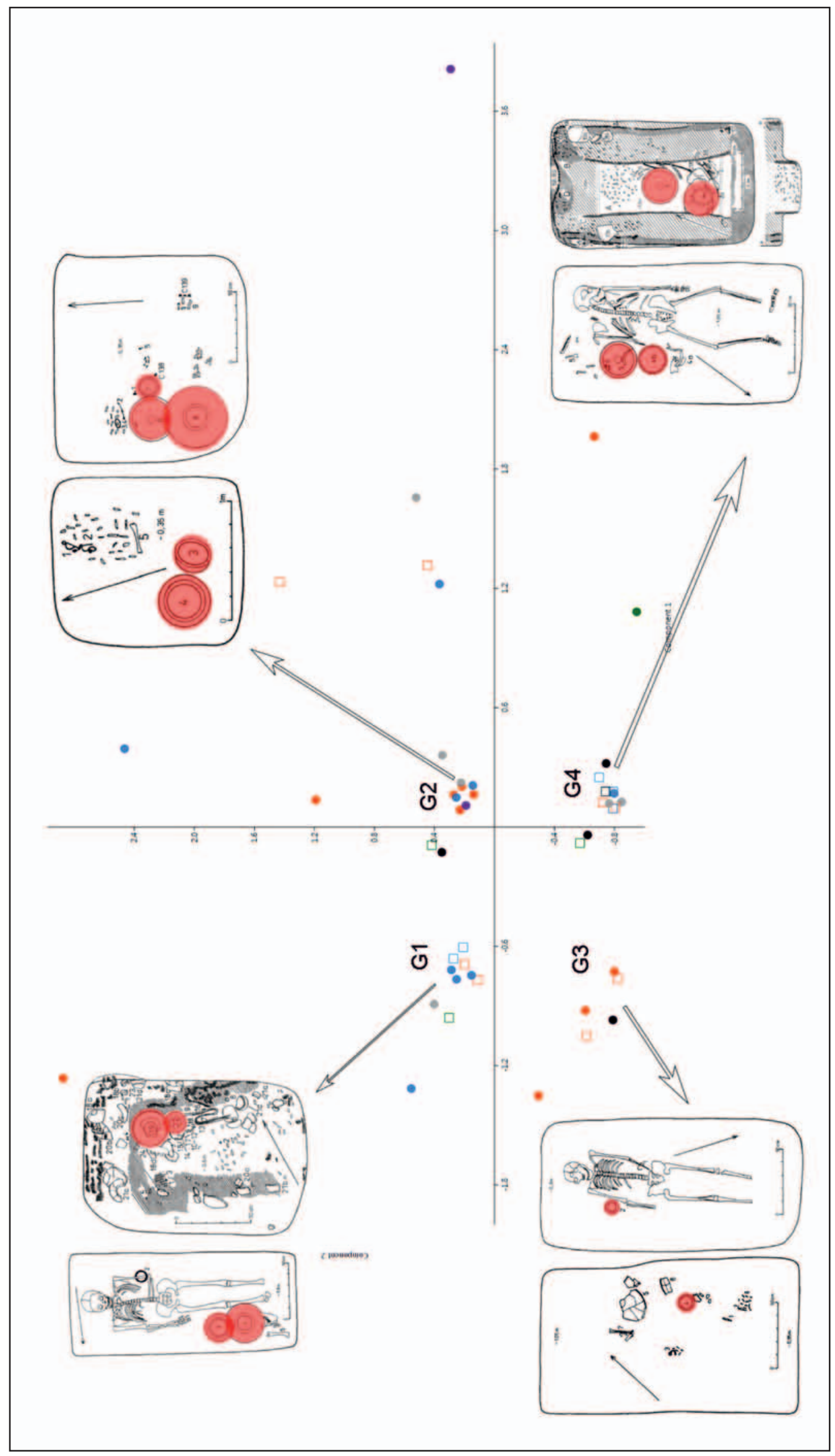

छै 1 तें

कै 苛

ه

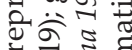

के ले क्षे

क्षे

पू कू के

艺

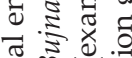

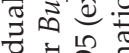

安宗

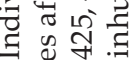

ट्टेंके ।

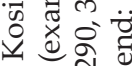

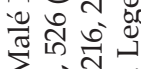

웅

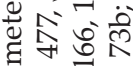

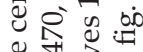

吉牙 ए

tै

ज्ञे लि

तै เо

च्चे సै

षे०

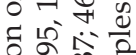

पु के क.

可 कू

埥造命

3 के 호ㅇㅝㅠ

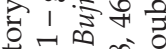

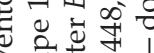

ह ठ

पे ज्ञ

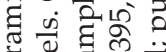

ठै

$\pi ?$ त

त के के

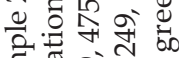

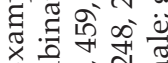

迎 है

믕 원

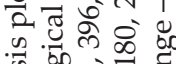

क की

वृ क्षैळ के

यद त्र

50 त

.

可

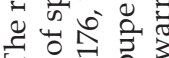

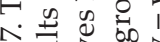

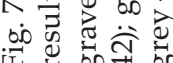




\section{Example 2}

Here, the conditions were similar, i. e. the defined form of the burial rite, identified ceramic type and sector. The difference was that the vessels' function was specified as ceramic containers. From the data matrix, lines and columns with no or single records were filtered out. Based on this, 51 burial complexes with 110 ceramic individuals entered the synthesis (Tab. 3: PCA 2). Besides, further data - rite form (inhumation and cremation) and dating were observed. I also used division of the graves into five categories (warrior/male/female/infant/double graves) based on biological data of human remains and archaeological data - grave goods (thus, I confronted functional and intentional data). When confronting the spatial results in relation to the temporal variation of the burial rite, there is an opportunity to use relative dating of the graves which should be a result of a separate analysis but - to make the article brief - I adopt it from another source (Repka 2015, tab. 47).

The data matrix comprised records = burial complexes and attributes = ceramic type (quantity), sector (quantity). In the PCA, first four components with eigenvalues between 0.2 and 0.8 were evaluated.

- Component 1 is defined by dominance of bowls and absence of small vessels; within them, it points to frequent deposition in sector $(2,-1)$ and $(2,-2)$, less frequent in sector $(-1,2)$.

- Component 2 describes mainly distribution of bottles in sectors $(1,1 ;-1,1 ;-1,4)$ and absence of vessels in sectors $(-1,0 ;-2,0)$.

- Component 3 is bipolar and determines the opposite relation of small vessels and bottles which are most frequent in sectors $(2,-1)$ and $(2,-2)$ and almost absent in sectors $(0,1 ;-1,1)$ and $(-1,-4)$.

- Component 4 is also bipolar and says that if pots and small vessels are together, terrines do not occur in the graves. The most frequent space is in sectors $(1,0 ; 1,4)$ and $(-1,4)$; on the contrary, pottery does not occur in sectors $(2,1)$ and $(2,2)$.

From the accompanying data in the diagram, we can derive the following:

1. we can observe 4 clear groups and several outliners defined by predominance of different types and spatial arrangements of pottery (Fig. 7);

2. from the aspect of the form of the burial rite, only group 2 is homogenous - cremation burials; in other groups, the form of burial proportion is equal;

3. from the aspect of gender, male burials are absent in group 3, female burials are absent in group 4;

4. only group 3 is homogenous in gender (women), in group 1, male burials prevail (others are mixed);

5. from the aspect of age, adultus is - logically - present in each group, infans and maturus occur mainly in groups 1 and 4;

6. from the aspect of chronology, deposition of pottery is not significant - only group 3 is typical of the beginning of LTB2; in LTC1, it is absent.

Comparison of the obtained results shows clearly that defining the function of the vessels and focusing on those which most probably correspond with the ceramic sets brings filtering of high variability and specifically evaluates the norms of the burial rite. Pottery with different functions as well as other corporal grave goods or elements of the burial rite bear information on identity, social structure and specifics of the funerary practices. The above-mentioned aspects would be unwanted in the case study and with "statistical noise", they would hide regularities in the burial rite which we are looking for. It is obvious in the second example, where the PCA results clearly document non-random distribution correlating with some aspects of the burial rite. Besides, we can observe some other facts in these results with a lower information value or presenting already known facts. As for the norms of use of vessels, we can see that the shape range of bottles varies the most with male and female burials. On the other hand, shape varieties of bowls vary at female burials only. From the aspect of position regarding human remains, bowls (in 17 cases deep S-shaped bowls in particular) occur in contact with the body or associated with the body. F1 bottles (9 cases) are found the furthest from the body.

On the level of Complex, results obtained from a larger space are evaluated. In such space, a certain degree of verification and primary interpretation should appear. It is suggested that regularities in depositing of individual ceramic shapes reflect regional differences in the normative burial practices. It opens a wider question which cannot be sufficiently solved in this article. I present the verification of results and application of the procedure on another than La Tène cemetery in the studied territory as simplified verification or a kind of introduction of the new topic. I have selected the cemetery in Maňa due to its sufficiently wider source base (although much information on the ceramic inventory is of lower quality). 


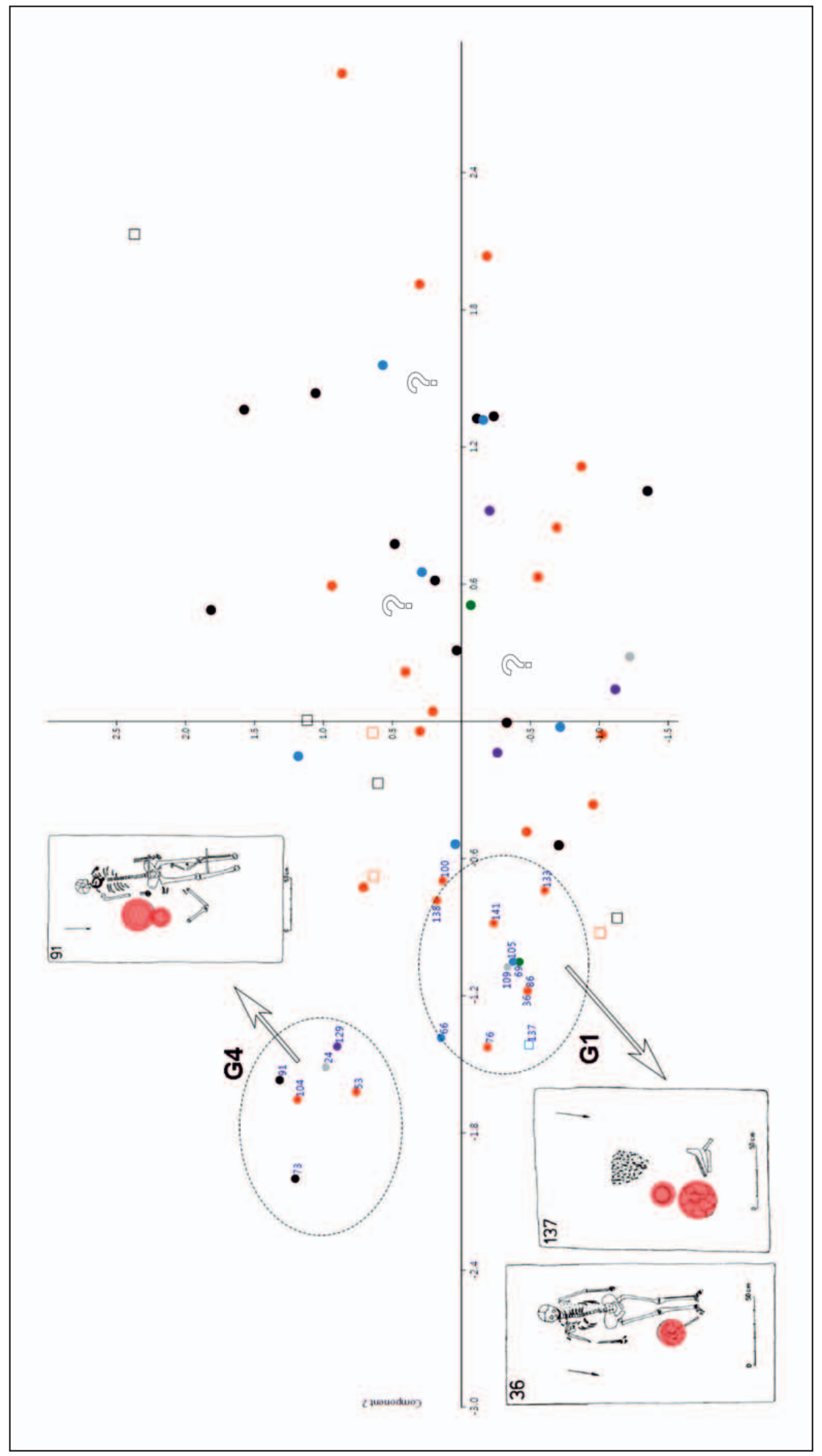

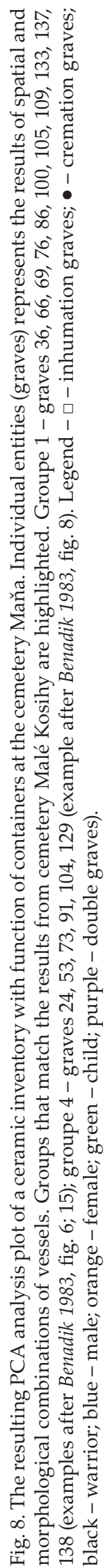




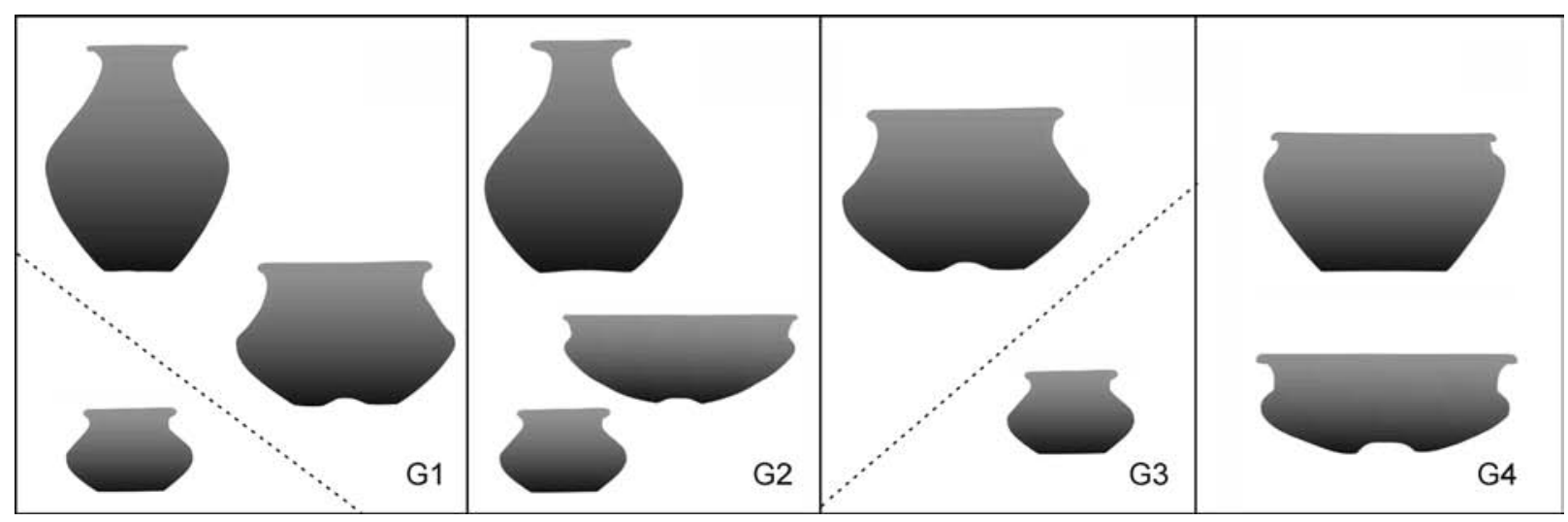

Fig. 9. Cemetery in Malé Kosihy. G1-4 - schematic representation of the most common combinations of ceramic additions in individual groups. Alternative variants are located behind the dashed line.

Now, I will sum up some basic facts. There are 101 graves at the cemetery in Maňa (82 inhumation graves, 19 cremation graves) in which pottery appeared (represented by min. one individual). It means 271 ceramic individuals in total (Tab. 2: 1. part). After application of morphological, microtopographic analysis on the level of Basic unit and definition of functions of the vessels (Tab. 2: 2. and 3. part), the basic source consists of 68 graves with 180 ceramic individuals (Tab. 4) spatially defined. The process of synthesis on the level of Structure is identical with the second example at the cemetery in Malé Kosihy so that the results can be objectively compared. The data matrix comprised records = burial complexes and attributes = ceramic type (quantity), sector (quantity). As a result of the significant inconsistency of the source, space data were normed (joint coordinates of the y-axis $1+2,3+4$ ). Also, lines and columns with no or single records were filtered out from the data matrix. The accompanying data included (like in example 2) the form of the burial rite and category of the graves. Based on this, 68 burials with 180 ceramic individuals entered the synthesis (Tab. 4: PCA 1). Two components with eigenvalues of 0.7 and 1.1 were evaluated in the PCA. The final diagram (Fig. 8) shows an increase of variability in the way of depositing pottery at this cemetery. It can be interpreted as evidence of burying of less homogenous groups of people. Nevertheless, pottery depositing forms analogous to Malé Kosihy occur in some of them (G1, G4). The obtained results in a way to confirm the legitimacy of the method searching for regularity in deposition of pottery. They also provide an opportunity to explain regional differences in burying and in the meaning of the ceramic sets. An important fact is that both cemeteries are similar in their sizes and length of the burying period (the question is whether the diachronic shift has an identical course). Thus, from the aspect of regional interpretation, the cemetery in Maňa provides evidence of higher variability of the buried population. Malé Kosihy, on the other hand, reflects a rather closed community in which the way of burying does not change very much.

\section{RESULTS AND DISCUSSION}

In our case study, we discovered that the ceramic set (vessels with the function of containers for corporal grave goods) occurs in certain clusters at the cemetery in Malé Kosihy. The clusters are typologically and spatially exclusive for four groups of the buried population. After including additional foils in form of age, gender, time and social category, individual groups can be evaluated as follows:

- The first group (Fig. 7; 9: G1) comprised mainly burials of male individuals buried by inhumation as well as cremation burial rite. Age of the buried most often corresponded with older (maturus) or very young (infans) individuals. Ceramic containers were deposited in graves by two - a bottle and a terrine (or a miniature vessel). In inhumation burials, they were placed next to the buried's feet, in cremation burial, they were deposited in the corner of the pit, away from the human remains.

- The second group (Fig. 7; 9: G2) consisted exclusively of cremation burials. It included men as well as women in the adultus age. The ceramic set comprised three vessels - a bottle, a bowl and a miniature vessel. They were deposited together in association with the body in the SW part of the grave pit.

- The third group (Fig. 7; 9: G3) is biritual. It represents burials of women of the adultus age. From the chronological point of view, it is typical for the beginning of stage LTB2. Ceramic containers most often included 
only one vessel - a terrine, rarely a miniature vessel. The pottery in inhumation burials was deposited at the right hand, in cremation burials, it was associated with the body, next to the wall of the grave pit.

- The fourth group (Fig. 7; 9: G4) is also biritual. It contains burials of older male individuals (maturus) and children. Ceramic containers were deposited in pairs and combined a deep and hollow bowl. In inhumation burials, they were located at the right hand of the buried individual, in cremation burials, they were associated with the bodies.

The analysis of the spatial and typological composition of the ceramic goods results in a statement that ceramic sets in the burial rite expressed local traditions of burying. A better confirmation of such assumptions would need application of the presented method on a larger number of cemeteries, but from the obtained results, we can come to the following conclusions. The ceramic set (meaning containers for corporal grave goods) is strongly connected with normative burial practices reflecting the communities. In the given time and space, the communities are the Celtic groups in the region of the lower Ipel river basin (Malé Kosihy) and the Žitava river basin (Maňa). By monitoring only one aspect of the burial rite, we cannot define normative burial practices for individual regions with certainty. On the other hand, we can sharply specify the meaning of pottery in the burial rite. The studied pottery in form of containers for corporal grave goods acquires cultural importance in the burial rite following from local traditions, not in the production method but in the form of the spatial and shape distribution (arrangement) during funerals. It represents a visual element of the burial rite complementing certain norms in the burial method. After all, the visual effect during the funeral has its own role in funerary ceremonies and was successfully distinguished in older periods as well (see Sørensen/Rebay 2005, 169-171). Using sets as containers for liquids and food can be - besides direct osteological evidence - verified only by a specifically targeted research (taking fresh samples for lipid analysis). Undoubtedly, their content played an important role in the funerary ceremony (and in the way of their disposal). Thanks to this, we can distinguish not only the protective or purifying function of the ceramic goods, function of urns or lids but also function of containers for corporal grave goods and mainly representative function. It is highly probable that vessels in graves were not - as for their function - solitary and their roles often blended. It is particularly significant with miniature vessels which could have had multiple functions - drinking vessels or boxes for spices or various cosmetics and oils (Repka 2017, 218).

Sufficient attention has been paid to the occurrence of ceramic grave goods from the aspect of their typological representation and regional differences. When evaluating the wider area from the Rhine region to the Iron Gates, M. Zeiler pointed to the fact that despite the homogeneity in form and decoration of vessels, significant regional differences occur during LTB1-C1. Especially when solving relative chronology based on grave pottery, there are problems with the evaluation of smaller areas. Besides, grave pottery from some regions is often unsuitable for chronological synchronization with settlement pottery (Zeiler $2010,122,123)$. These facts confirm the assumption that the typological composition of ceramic sets very loosely reflects the chronological development. It rather reflects local traditions in burying as suggested by the case study. Despite this, the spatial analysis focused on individual variants of ceramic shapes has not brought any relevant results. More sensitive evaluation of the vessels' sizes would be a solution. Evaluation of some variants of bottle shapes showed that their proportions change in time (e. g. variant Hu 1a according to Zeiler 2010, 123). On the other hand, the composition of the ceramic set can point to gender conditionality of rituals. In the case study of Malé Kosihy, it was suggested by the combinations of deep and hollow bowls in the fourth group and disposal of terrine or miniature vessels in the third group. Mainly disposal of miniature vessels in contact with human remains is documented more frequently in female burials and less in children's burials (Repka 2017, 218). In the wider territory of the La Tène culture, position of some variants (terrines and barrel-shaped pots) changes from typically female to typically male corporal grave goods between LTB2 and LTB2/C1 (variants Bs 1a-Bs 3 according to Zeiler 2010, 122).

Distinguishing of shapes of vessels can point to their function, e. g. at the cemetery in Dubník, J. Bujna defined tall vessels which carried liquid or loose content, on the other hand, there were shallow vessels used for smaller pieces of meaty meals (Bujna 1991, 236). Another view of the technological production of vessels says that they were more often used for serving food than liquids. Storage vessels or vessels for food preparation are rarer (Zeiler 2010, 122). Only forms of deep bowls (Bujna 1998, 303) or bowls with inverted rims could have contained liquids (Zeiler 2010,122). Now, a question arises whether the function of ceramic containers can be specified also by the volume of the vessels. This assumption follows from the premise of ceramic sets as parts of burial-feasts. The attempt to detect this aspect is strongly limited by the range of shapes which - despite included volume indexes and 3D calculations of the vessels' 
volume - does not allow more precise division and does not represent relevant indicators in the context of burial rituals. ${ }^{6}$ Morphological variations are a problem even with a finer typological classification; they disable application of generally valid indexes. 3D modelling of volumes for each vessel separately seems to be ineffective from the aspect of time and its relative deflection is still determined by a certain approximation in form of $2 \mathrm{D}$ documentation of pottery profiles. This problem could only be solved by $3 \mathrm{D}$ scanning of whole vessels, which is limited by the source base.

Finally, we could add that although much attention was paid to observation of disposal of pottery in graves, it always aimed at definition of forms of ceramic sets which were added for storing food (e. $\mathrm{g}$. Bujna 1991, 236-239). Based on the obtained results, it seems that the ceramic set did not necessarily contain only containers for corporal grave goods but also included vessels with representation function complementing the specific composition respecting the expression of funerary practices.

\section{CONCLUSION}

The research of ceramic goods brings new opportunities to study the burial rite. The goal of this article was to bring a new perspective to a rather old problem. Various options of research of the grave pottery' shape and spatial variability bring many technical and interpretation complications. The main used method was microtopography of corporal grave goods which follows from the concepts of microarchaeology. The correct technical setting of individual steps makes our view of individual situations - which are not always individually solved - more precise. These procedures were included in a wider methodological concept called Linked analytical process (LAP). The role of pottery in funerary practices was described by a theoretical model following from the variability of the burial rite. Unlike "traditional" approaches or approaches strictly respecting the procedure of the archaeological method, it was possible - thanks to the LAP - to carry out a series of detailed observations and evaluate them always in a closed environment (of a grave or a cemetery) without losing the necessary perspective. Since this procedure was justified by a preliminary model, I did not have to adhere to the variability of vessels' disposal in my interpretation; I could also directly evaluate the variability of the burial rite. Thus, it was possible to created types or norms of the burial rite without being limited by formal classification (of forms of rites, categories of burials, etc.). These additional aspects which are in most works used at the start of the analysis (e. g. division of graves into inhumation and cremation burials, or according to gender), enter the LAP sequence later, supporting the synthesis of the structures. The microtopography itself aimed more specifically at the relation to the body better solves the variability of the ceramic goods. Connecting the coordinate system with morphological classification of vessels is an illustration of how to deal with technical problems of formalized procedures. Unlike "traditional" approaches, we took the integrity of the source (Basic unit) as well as the quantitative aspect (Structures) into consideration without premature selection of the source and limitation of interpretation options. At the same time, at the analysis of the variability, function of the vessels was taken into consideration, significantly influencing the obtained results. Filtering out the intentionally broken pottery, lids and urns, we obtained the aimed collection - a ceramic set. Thus, we can determine the variability of the burial rite as early as the level of Structure. However, as we suggested in the case study, for interpretation, it is necessary to include it in a higher entity, such as development of burying, which includes an additional problem - often on the level of Complex. It was proved in the presented case study that ceramic corporal grave goods in form of containers (ceramic set) occur at the cemetery in Malé Kosihy in groups which are typologically and spatially exclusive for four groups of the buried population. Two similar groups could be observed at the cemetery in Maňa. It follows from the results that ceramic sets reflect several normative funerary practices and point to local traditions in burying. On the regional level, these results can better specify differences in individual groups of the La Tène culture. The study of the regional variability in burying will bring more profound knowledge of the structure of the La Tène culture. However, it will be necessary to apply the above-mentioned procedures on more cemeteries from the territory of SW Slovakia. We must also bear in mind that the variability of the burial rite consists of several elements. Grave pottery is only one of them and this study points to the importance of the ceramic set as an indicator of local traditions in burying. They represent the method which the past societies used to deposit and arrange vessels functioning as containers for corporal grave goods in the graves.

Translated by Mgr. Viera Tejbusová

\footnotetext{
6 Analysis is part of an unpublished dissertation defended at $\mathrm{KARCH}$ Constantine the Philosopher University Nitra (Styk
} $2018,119,120)$. 
Tab. 1. Basic data from Malé Kosihy cemetery. 1. part - attributes of burial rite. B. r. - Burial rite (inhumation/cremation); Sex - anthropological estimation ( $\mathrm{M}$ - male, F - female); Age - anthropological estimation (I - infans, J - juvenis, A - adultus, $\mathrm{M}$ - maturus); Cat. - social categories ( $\mathrm{W}$ - warrior graves, $\mathrm{M}$ - male graves, $\mathrm{F}$ - female graves, $\mathrm{Ch}$ - childe graves, D - double graves); NCI - number of pottery individuals per grave. 2. part - count of pottery types. Bot. - bottles; Bow. - bowls; P - pots; V - vases; $\mathrm{T}$ - terrines; $\mathrm{MnV}$ - miniature vessels; ? - unidentified. 3. part - pottery function. C - container; Rf - ritual function; Urn, Lid; ? - unknown function; NSC - number of sector classified types.

\begin{tabular}{|c|c|c|c|c|c|c|c|c|c|c|c|c|c|c|c|c|c|c|}
\hline \multirow{3}{*}{ Grave } & \multicolumn{5}{|c|}{ 1.part } & \multicolumn{7}{|c|}{ 2.part } & \multicolumn{6}{|c|}{ 3. part } \\
\hline & \multicolumn{5}{|c|}{ Attributes of burial rite } & \multicolumn{7}{|c|}{ Count of pottery types } & \multicolumn{6}{|c|}{ Pottery function } \\
\hline & B. $r$. & Sex & Age & Cat. & NPI & Bot. & Bow. & $\mathrm{P}$ & $\mathrm{V}$ & $\mathrm{T}$ & $\mathrm{MnV}$ & ? & C & Rf & Urn & Lid & $?$ & NSC \\
\hline MK1 & C & ? & $\mathrm{M}$ & $\mathrm{M}$ & 5 & 3 & 1 & 1 & - & - & - & - & 4 & 1 & - & - & - & 5 \\
\hline MK6 & C & ? & - & W & 5 & 3 & 2 & - & - & - & - & - & - & 5 & - & - & - & 5 \\
\hline MK8 & C & M & M & M & 2 & - & 2 & - & - & - & - & - & 1 & 1 & - & - & - & 2 \\
\hline MK9 & C & $\mathrm{M}$ & $\mathrm{M}$ & M & 8 & 2 & 1 & 1 & - & 1 & 3 & - & 4 & 4 & - & - & - & 8 \\
\hline MK12 & C & ? & - & ? & 1 & 1 & - & - & - & - & - & - & - & & - & - & 1 & 1 \\
\hline MK28 & C & $\mathrm{F}$ & 1 & $\mathrm{Ch}$ & 6 & 2 & 3 & 1 & - & - & - & - & 2 & 3 & 1 & - & - & 6 \\
\hline MK31 & C & $\mathrm{M}$ & $\mathrm{M}$ & W & 4 & 3 & 1 & - & - & - & - & - & - & 4 & - & - & - & 0 \\
\hline MK34 & C & ? & - & ? & 2 & - & 1 & - & - & - & - & 1 & - & 1 & - & - & 1 & 0 \\
\hline MK59 & C & ? & M & ? & 3 & 1 & 1 & - & - & - & - & 1 & - & - & - & - & 3 & 2 \\
\hline MK62 & C & ? & M & W & 6 & 3 & 1 & 1 & - & - & 1 & - & 2 & 4 & - & - & - & 6 \\
\hline MK68 & I & ? & 1 & $\mathrm{Ch}$ & 2 & 1 & - & - & - & - & - & 1 & - & - & - & - & 2 & 2 \\
\hline MK75 & C & ? & - & W & 2 & 1 & - & - & 1 & - & - & - & - & 2 & - & - & - & 0 \\
\hline MK83 & C & - & - & - & 3 & - & 1 & - & - & - & 1 & 1 & 2 & - & - & - & 1 & 3 \\
\hline MK84 & C & ? & - & $\mathrm{M}$ & 3 & 1 & 1 & - & - & - & - & 1 & - & 3 & - & - & - & 2 \\
\hline MK89 & C & ? & - & $\mathrm{F}$ & 3 & 1 & - & - & - & - & - & 2 & - & 3 & - & - & - & 2 \\
\hline MK95 & 1 & $\mathrm{M}$ & A & $\mathrm{M}$ & 2 & 1 & - & - & - & 1 & - & - & 2 & - & - & - & - & 2 \\
\hline MK103 & C & ? & - & $\mathrm{F}$ & 3 & 1 & - & - & - & 1 & - & 1 & - & - & - & - & 3 & 3 \\
\hline MK109 & 1 & ? & 1 & $\mathrm{Ch}$ & 2 & 1 & - & - & - & - & 1 & - & 2 & - & - & - & - & 2 \\
\hline MK120 & C & ? & - & ? & 1 & - & 1 & - & - & - & - & - & - & - & - & - & 1 & 1 \\
\hline MK133 & C & - & - & - & 2 & 2 & - & - & - & - & - & - & - & 2 & - & - & - & 2 \\
\hline MK134 & - & - & - & - & 3 & 2 & 1 & - & - & - & - & - & 1 & - & - & - & 2 & 0 \\
\hline MK142 & C & $\mathrm{F}$ & $\mathrm{J}$ & $\mathrm{F}$ & 3 & 2 & 1 & - & - & - & - & - & - & 3 & - & - & - & 3 \\
\hline MK149 & C & M & A & W & 5 & 1 & 2 & - & - & 1 & 1 & - & 5 & - & - & - & - & 5 \\
\hline MK153 & C & ? & - & ? & 3 & 1 & 1 & - & - & - & - & 1 & 1 & 1 & - & - & 1 & 2 \\
\hline MK166 & 1 & $\mathrm{~F}$ & A & $\mathrm{F}$ & 1 & - & - & - & - & - & 1 & - & 1 & - & - & - & - & 1 \\
\hline MK168 & C & $\mathrm{F}$ & A & $\mathrm{F}$ & 5 & 1 & 1 & - & - & 1 & 2 & - & 2 & 3 & - & - & - & 5 \\
\hline MK171 & C & ? & - & ? & 1 & - & 1 & - & - & - & - & - & - & 1 & - & - & - & 1 \\
\hline MK176 & C & ? & A & W & 5 & 1 & 2 & - & - & 1 & - & 1 & 3 & 2 & - & - & - & 3 \\
\hline MK180 & 1 & ? & M & $\mathrm{F}$ & 3 & 1 & 2 & - & - & - & - & - & 1 & - & - & - & 2 & 3 \\
\hline MK182 & 1 & $\mathrm{~F}$ & M & $\mathrm{F}$ & 4 & 1 & 2 & 1 & - & - & - & - & 4 & - & - & - & - & 4 \\
\hline MK183 & C & ? & - & ? & 2 & 1 & 1 & - & - & - & - & - & - & 2 & - & - & - & 2 \\
\hline MK184 & C & - & - & - & 2 & 1 & 1 & - & - & - & - & - & - & 2 & - & - & - & 0 \\
\hline MK188 & 1 & ? & A & $\mathrm{F}$ & 1 & - & 1 & - & - & - & - & - & - & - & - & - & 1 & 1 \\
\hline MK189 & C & $\mathrm{F}$ & - & $\mathrm{F}$ & 2 & 1 & 1 & - & - & - & - & - & 2 & - & - & - & - & 2 \\
\hline MK192 & C & $?$ & - & $\mathrm{F}$ & 6 & 3 & 1 & - & - & 1 & - & 1 & 2 & 4 & - & - & - & 6 \\
\hline MK197 & C & $?$ & - & ? & 2 & 1 & - & - & - & - & - & 1 & - & 1 & - & - & 1 & 1 \\
\hline MK204 & C & ? & - & ? & 1 & - & - & - & - & - & - & 1 & - & - & - & - & 1 & 1 \\
\hline MK216 & C & $?$ & A & $\mathrm{F}$ & 3 & 1 & - & - & - & 1 & 1 & - & 1 & - & - & - & 2 & 3 \\
\hline MK217 & C & $\mathrm{F}$ & - & $\mathrm{F}$ & 12 & 4 & 4 & 1 & - & - & 3 & - & 6 & 6 & - & - & - & 12 \\
\hline MK221 & I & $\mathrm{F}$ & M & $\mathrm{F}$ & 2 & 1 & 1 & - & - & - & - & - & - & 2 & - & - & - & 2 \\
\hline MK222 & C & $?$ & 1 & $\mathrm{Ch}$ & 2 & 1 & 1 & - & - & - & - & - & - & 1 & - & - & 1 & 2 \\
\hline MK227 & C & ? & - & $\mathrm{F}$ & 3 & 1 & 1 & - & - & - & - & 1 & 3 & - & - & - & - & 3 \\
\hline MK234 & C & ? & A & W & 3 & - & 1 & 1 & - & - & - & 1 & 1 & 1 & - & - & 1 & 3 \\
\hline
\end{tabular}


Tab. 1. Continuation.

\begin{tabular}{|c|c|c|c|c|c|c|c|c|c|c|c|c|c|c|c|c|c|c|}
\hline \multirow{3}{*}{ Grave } & \multicolumn{5}{|c|}{ 1.part } & \multicolumn{7}{|c|}{ 2. part } & \multicolumn{6}{|c|}{ 3. part } \\
\hline & \multicolumn{5}{|c|}{ Attributes of burial rite } & \multicolumn{7}{|c|}{ Count of pottery types } & \multicolumn{6}{|c|}{ Pottery function } \\
\hline & B. $r$. & Sex & Age & Cat. & NPI & Bot. & Bow. & $\mathrm{P}$ & $\mathrm{V}$ & $\mathrm{T}$ & $\mathrm{MnV}$ & ? & C & $\mathrm{Rf}$ & Urn & Lid & ? & NSC \\
\hline MK235 & C & ? & M & M & 4 & 2 & 2 & - & - & - & - & - & 1 & 3 & - & - & - & 4 \\
\hline MK247 & 1 & ? & 1 & $\mathrm{Ch}$ & 2 & 1 & - & - & - & - & - & 1 & - & - & - & - & 2 & 0 \\
\hline MK248 & C & ? & - & M & 7 & 2 & 2 & - & - & 1 & - & 2 & 2 & 4 & - & - & 1 & 6 \\
\hline MK249 & 1 & M & $\mathrm{J}$ & M & 2 & - & 1 & - & - & - & - & 1 & 1 & 1 & - & - & - & 2 \\
\hline MK274 & C & ? & M & $\mathrm{F}$ & 4 & 1 & 3 & - & - & - & - & - & 3 & 1 & - & - & - & 4 \\
\hline MK283 & C & $?$ & $M$ & $D$ & 5 & 3 & 2 & - & - & - & - & - & 2 & & - & - & 3 & 5 \\
\hline MK290 & C & $\mathrm{F}$ & - & $\mathrm{F}$ & 2 & - & 1 & 1 & - & - & - & - & 1 & 1 & - & - & - & 2 \\
\hline MK298 & C & $\mathrm{M}$ & A & $\mathrm{M}$ & 4 & 1 & 2 & 1 & - & - & - & - & 2 & 1 & - & 1 & - & 4 \\
\hline MK307 & 1 & ? & - & $\mathrm{F}$ & 1 & - & 1 & - & - & - & - & - & 1 & - & - & - & - & 1 \\
\hline MK313 & 1 & $?$ & A & $?$ & 3 & 1 & - & - & - & - & - & 2 & - & - & - & - & 3 & 0 \\
\hline MK316 & I & $\mathrm{F}$ & $M$ & $\mathrm{~F}$ & 1 & - & - & - & - & 1 & - & - & - & 1 & - & - & - & 1 \\
\hline MK330 & 1 & $\mathrm{~F}$ & $M$ & $\mathrm{~F}$ & 2 & - & 1 & - & - & 1 & - & - & 1 & - & - & 1 & - & 2 \\
\hline MK331 & 1 & $\mathrm{~F}$ & $M$ & $\mathrm{~F}$ & 5 & 2 & 2 & 1 & - & - & - & - & 5 & - & - & - & - & 5 \\
\hline MK335 & I & $\mathrm{F}$ & A & $\mathrm{F}$ & 2 & 1 & 1 & - & - & - & - & - & 1 & - & - & 1 & - & 2 \\
\hline MK345 & 1 & $M$ & - & $M$ & 1 & 1 & - & - & - & - & - & - & - & - & - & - & 1 & 1 \\
\hline MK346 & C & $\mathrm{F}$ & A & $\mathrm{F}$ & 5 & - & 2 & - & - & - & 1 & 2 & - & 2 & - & - & 3 & 2 \\
\hline MK347 & - & - & - & - & 2 & 1 & - & - & - & - & - & 1 & - & - & - & - & 2 & 2 \\
\hline MK356 & 1 & $\mathrm{~F}$ & A & $\mathrm{F}$ & 4 & 1 & 1 & - & - & 1 & - & 1 & 2 & 1 & - & - & 1 & 4 \\
\hline MK357 & C & $?$ & - & $?$ & 1 & - & - & - & - & - & - & 1 & - & - & - & - & 1 & 1 \\
\hline MK394 & 1 & $?$ & $M$ & $M$ & 3 & - & 1 & - & - & - & 1 & 1 & 1 & 2 & - & - & - & 3 \\
\hline MK395 & 1 & $M$ & $\mathrm{M}$ & $M$ & 2 & - & 1 & - & 1 & - & - & - & 1 & 1 & - & - & - & 2 \\
\hline MK396 & 1 & $\mathrm{~F}$ & $A$ & $\mathrm{~F}$ & 2 & 1 & 1 & - & - & - & - & - & 2 & - & - & - & - & 2 \\
\hline MK425 & C & $?$ & - & $\mathrm{F}$ & 3 & - & - & - & - & 1 & - & 2 & 1 & - & - & - & 2 & 3 \\
\hline MK431 & 1 & $?$ & $\mathrm{~J}$ & $?$ & 3 & - & 1 & - & - & - & - & 2 & 1 & 2 & - & - & - & 3 \\
\hline MK437 & C & $\mathrm{F}$ & $\mathrm{M} ?$ & D & 8 & 1 & 4 & 2 & - & 1 & - & - & 6 & 2 & - & - & - & 8 \\
\hline MK448 & C & $?$ & $M$ & W & 3 & 2 & 1 & - & - & - & - & - & 1 & 2 & - & - & - & 3 \\
\hline MK450 & - & - & - & - & 3 & 1 & - & 1 & - & - & 1 & - & 2 & 1 & - & - & - & 0 \\
\hline MK452 & C & $?$ & A & $\mathrm{F}$ & 3 & 3 & - & - & - & - & - & - & - & 3 & - & - & - & 3 \\
\hline MK453 & C & $M$ & $M$ & W & 4 & 1 & 2 & - & - & 1 & - & - & 2 & 2 & - & - & - & 4 \\
\hline MK459 & C & ? & - & $?$ & 3 & 1 & 1 & - & - & - & 1 & - & 3 & - & - & - & - & 3 \\
\hline MK468 & C & ? & $\mathrm{J}$ & $M$ & 1 & - & 1 & - & - & - & - & - & - & 1 & - & - & - & 1 \\
\hline MK469 & 1 & M & M & $M$ & 1 & - & 1 & - & - & - & - & - & 1 & - & - & - & - & 1 \\
\hline MK470 & 1 & ? & $\mathrm{J}$ & M & 2 & 1 & 1 & - & - & - & - & - & 1 & - & - & 1 & - & 2 \\
\hline MK475 & 1 & ? & 1 & $\mathrm{Ch}$ & 4 & 1 & 1 & 1 & - & - & 1 & - & 4 & - & - & - & - & 4 \\
\hline MK477 & C & $?$ & - & W & 5 & 1 & 1 & 1 & - & - & - & 2 & 1 & 4 & - & - & - & 5 \\
\hline MK482 & C & $?$ & A & $M$ & 3 & 1 & 1 & - & - & 1 & - & - & 2 & 1 & - & - & - & 3 \\
\hline MK483 & C & - & - & - & 8 & 4 & 4 & - & - & - & - & - & 3 & 5 & - & - & - & 8 \\
\hline MK485 & C & $?$ & A & $M$ & 3 & 1 & 2 & - & - & - & - & - & 3 & - & - & - & - & 3 \\
\hline MK488 & C & $?$ & - & $\mathrm{F}$ & 1 & 1 & - & - & - & - & - & - & - & 1 & - & - & - & 1 \\
\hline MK490 & 1 & $?$ & 1 & $\mathrm{Ch}$ & 1 & - & 1 & - & - & - & - & - & - & - & - & - & 1 & 0 \\
\hline MK495 & C & $?$ & - & $?$ & 3 & - & 1 & - & - & 1 & 1 & - & 2 & 1 & - & - & - & 3 \\
\hline MK506 & C & $M$ & $\mathrm{M}$ & $M$ & 8 & 5 & 3 & - & - & - & - & - & 1 & 6 & - & 1 & - & 8 \\
\hline MK507 & 1 & $?$ & 1 & $\mathrm{Ch}$ & 4 & 1 & 1 & 1 & - & - & 1 & - & 3 & 1 & - & - & - & 4 \\
\hline MK526 & C & $?$ & $M$ & $M$ & 4 & 1 & 1 & - & - & 1 & - & 1 & 1 & 1 & 1 & 1 & - & 4 \\
\hline MK535 & C & $?$ & - & $M$ & 3 & 1 & 2 & - & - & - & - & - & - & - & - & - & 3 & 2 \\
\hline MK541 & 1 & $?$ & $\mathrm{M}$ & $?$ & 1 & 1 & - & - & - & - & - & - & - & 1 & - & - & - & 0 \\
\hline$\sum 89$ & $28 / 58$ & & & & 285 & 98 & 96 & 16 & 2 & 18 & 21 & 34 & 116 & 114 & 2 & 6 & 47 & 250 \\
\hline
\end{tabular}


Tab. 2. Basic data from Maňa cemetery. 1. part - attributes of burial rite. B.r. - Burial rite (inhumation/cremation); Sex - anthropological estimation ( $\mathrm{M}$ - male, F - female); Age - anthropological estimation (I - infans, J - juvenis, A - adultus, $\mathrm{M}$ - maturus); Cat. - social categories ( $\mathrm{W}$ - warrior graves, $\mathrm{M}$ - male graves, $\mathrm{F}$ - female graves, $\mathrm{Ch}$ - childe graves, D - double graves); NCI - number of pottery individuals per grave. 2. part - count of pottery types. Bot. - bottles; Bow. - bowls; P - pots; V - vases; T - terrines; MnV - miniature vessels; ? - unidentified. 3. part - pottery function. C - container; Rf - ritual function; Urn, Lid; ? - unknown function; NSC - number of sector classified types.

\begin{tabular}{|c|c|c|c|c|c|c|c|c|c|c|c|c|c|c|c|c|c|c|}
\hline \multirow{3}{*}{ Grave } & \multicolumn{5}{|c|}{ 1.part } & \multicolumn{7}{|c|}{ 2.part } & \multicolumn{6}{|c|}{ 3. part } \\
\hline & \multicolumn{5}{|c|}{ Attributes of burial rite } & \multicolumn{7}{|c|}{ Count of pottery types } & \multicolumn{6}{|c|}{ Pottery function } \\
\hline & B.r. & Sex & Age & Cat. & $\mathrm{NPI}$ & Bot. & Bow. & $P$ & v & $\mathrm{T}$ & $\mathrm{MnV}$ & $?$ & C & $\mathrm{Rf}$ & Urn & Lid & $?$ & NSC \\
\hline M3 & 1 & $?$ & - & $\mathrm{F}$ & 3 & 1 & 2 & - & - & - & - & - & 3 & - & - & - & - & 3 \\
\hline M4 & 1 & $?$ & 1 & $\mathrm{Ch}$ & 4 & - & 1 & 1 & - & - & 2 & - & 4 & - & - & - & - & 0 \\
\hline M6 & C & $?$ & - & $?$ & 6 & 1 & 2 & 1 & - & 1 & 1 & - & 6 & - & - & - & - & 0 \\
\hline M7 & 1 & $?$ & I & $\mathrm{Ch}$ & 1 & - & 1 & - & - & - & - & - & 1 & - & - & - & - & 0 \\
\hline M8 & C & $?$ & - & w & 2 & - & - & 2 & - & - & - & - & 2 & - & - & - & - & 0 \\
\hline M10 & 1 & $M$ & A & W & 3 & 1 & 1 & - & - & 1 & - & - & 2 & - & - & 1 & - & 3 \\
\hline M11 & C & $?$ & - & W & 3 & 1 & - & 2 & - & - & - & - & 3 & - & - & - & - & 0 \\
\hline M12 & C & $?$ & - & W & 1 & 1 & - & - & - & - & - & - & 1 & - & - & - & - & 0 \\
\hline M13 & 1 & $\mathrm{~F}$ & A & $\mathrm{F}$ & 2 & 1 & 1 & - & - & - & - & - & 1 & 1 & - & - & - & 1 \\
\hline M14 & 1 & $F+M$ & A & D & 5 & 2 & 1 & 1 & - & 1 & - & - & 5 & - & - & - & - & 5 \\
\hline M15 & 1 & $\mathrm{M}$ & A & W & 4 & 1 & 3 & - & - & - & - & - & 3 & - & - & - & 1 & 3 \\
\hline M16 & 1 & $\mathrm{~F}$ & A & $\mathrm{F}$ & 4 & 3 & 1 & - & - & - & - & - & 4 & - & - & - & - & 4 \\
\hline M17 & C & $?$ & - & W & 3 & 1 & 1 & 1 & - & - & - & - & 3 & - & - & - & - & 0 \\
\hline M18 & 1 & $?$ & - & $\mathrm{F}$ & 5 & 2 & - & - & - & - & - & 3 & 5 & - & - & - & - & 0 \\
\hline M19 & 1 & $M$ & - & $M$ & 3 & 2 & 1 & - & - & - & - & - & 3 & - & - & - & - & 3 \\
\hline M20 & 1 & $M$ & A & $M$ & 3 & 2 & 1 & - & - & - & - & - & 3 & - & - & - & - & 3 \\
\hline M21 & 1 & $?$ & $M$ & $M$ & 2 & 1 & - & - & - & - & - & 1 & 1 & - & - & - & 1 & 2 \\
\hline M23 & 1 & $?$ & - & $\mathrm{F}$ & 3 & 2 & 1 & - & - & - & - & - & 2 & 1 & - & - & - & 2 \\
\hline M24 & I & $?$ & - & $?$ & 2 & - & - & - & - & 1 & 1 & - & 2 & - & - & - & - & 2 \\
\hline M27 & 1 & $?$ & - & $\mathrm{F}$ & 4 & 2 & - & - & - & 1 & - & 1 & 3 & 1 & - & - & - & 3 \\
\hline M28 & 1 & $M+F$ & $A$ & D & 5 & 2 & 2 & - & - & 1 & - & - & 5 & - & - & - & - & 5 \\
\hline M30 & I & $M$ & - & $M$ & 3 & 1 & 1 & - & 1 & - & - & - & 3 & - & - & - & - & 3 \\
\hline M31 & 1 & $M$ & - & $M$ & 1 & 1 & - & - & - & - & - & - & 1 & - & - & - & - & 0 \\
\hline M32 & C & $M$ & - & W & 5 & - & 3 & 1 & - & 1 & - & - & 3 & - & 1 & 1 & - & 3 \\
\hline M35 & 1 & $?$ & - & $M$ & 2 & 2 & - & - & - & - & - & - & 1 & - & - & - & 1 & 1 \\
\hline M36 & 1 & $\mathrm{~F}$ & - & $\mathrm{F}$ & 1 & 1 & - & - & - & - & - & - & 1 & - & - & - & - & 1 \\
\hline M38 & 1 & $M$ & - & $M$ & 3 & 1 & 2 & - & - & - & - & - & 3 & - & - & - & - & 3 \\
\hline M39 & 1 & $?$ & - & $\mathrm{F}$ & 3 & 2 & 1 & - & - & - & - & - & 3 & - & - & - & - & 3 \\
\hline M40 & 1 & $M$ & - & W & 3 & 1 & 2 & - & - & - & - & - & 3 & - & - & - & - & 3 \\
\hline M42 & 1 & $?$ & 1 & $\mathrm{Ch}$ & 1 & 1 & - & - & - & - & - & - & 1 & - & - & - & - & 0 \\
\hline M43 & 1 & $M$ & A & W & 3 & 2 & 1 & - & - & - & - & - & 3 & - & - & - & - & 3 \\
\hline M44 & 1 & $?$ & - & $M$ & 1 & 1 & - & - & - & - & - & - & 1 & - & - & - & - & 0 \\
\hline M47 & I & $?$ & - & $\mathrm{F}$ & 3 & - & - & 2 & - & - & - & 1 & 3 & - & - & - & - & 0 \\
\hline M50 & 1 & $?$ & 1 & $\mathrm{Ch}$ & 1 & - & - & - & - & - & - & 1 & 1 & - & - & - & - & 0 \\
\hline M53 & 1 & $\mathrm{~F}$ & - & $\mathrm{F}$ & 3 & - & - & - & - & 1 & 2 & - & 2 & - & - & - & 1 & 2 \\
\hline M55 & 1 & $?$ & - & $?$ & 2 & - & 1 & - & - & - & - & 1 & 2 & - & - & - & - & 0 \\
\hline M58 & 1 & $M$ & A & W & 4 & - & 3 & 1 & - & - & - & - & 4 & - & - & - & - & 0 \\
\hline M59 & I & $?$ & - & W & 4 & 1 & 1 & 2 & - & - & - & - & 4 & - & - & - & - & 4 \\
\hline M60 & 1 & $M$ & - & W & 3 & 1 & 2 & - & - & - & - & - & 3 & - & - & - & - & 3 \\
\hline M61 & 1 & $M$ & $M$ & W & 3 & - & 2 & - & - & 1 & - & - & 3 & - & - & - & - & 3 \\
\hline M62 & I & $?$ & - & $\mathrm{F}$ & 4 & 2 & 2 & - & - & - & - & - & 4 & - & - & - & - & 4 \\
\hline M63 & 1 & $F$ & $M$ & $F$ & 4 & - & 3 & - & - & - & 1 & - & 4 & - & - & - & - & 0 \\
\hline M64 & 1 & $\mathrm{~F}$ & $A$ & $\mathrm{~F}$ & 7 & 2 & 3 & - & - & 2 & - & - & 7 & - & - & - & - & 7 \\
\hline
\end{tabular}


Tab. 2. Continuation.

\begin{tabular}{|c|c|c|c|c|c|c|c|c|c|c|c|c|c|c|c|c|c|c|}
\hline \multirow{3}{*}{ Grave } & \multicolumn{5}{|c|}{ 1.part } & \multicolumn{7}{|c|}{ 2.part } & \multicolumn{6}{|c|}{ 3. part } \\
\hline & \multicolumn{5}{|c|}{ Attributes of burial rite } & \multicolumn{7}{|c|}{ Count of pottery types } & \multicolumn{6}{|c|}{ Pottery function } \\
\hline & B.r. & Sex & Age & Cat. & NPI & Bot. & Bow. & $\mathrm{P}$ & $\mathrm{V}$ & $\mathrm{T}$ & $\mathrm{MnV}$ & ? & C & $\mathrm{Rf}$ & Urn & Lid & ? & NSC \\
\hline M66 & 1 & M & - & M & 1 & - & - & 1 & - & - & - & - & 1 & - & - & - & - & 1 \\
\hline M67 & C & $?$ & - & ? & 1 & - & - & - & - & - & - & 1 & - & - & 1 & - & - & 0 \\
\hline M68 & C & ? & - & W & 2 & 2 & - & - & - & - & - & - & 2 & - & - & - & - & 2 \\
\hline M69 & 1 & ? & 1 & $\mathrm{Ch}$ & 3 & 1 & 1 & 1 & - & - & - & - & 1 & 2 & - & - & - & 2 \\
\hline M73 & 1 & M & $J$ & W & 3 & - & - & - & - & 3 & - & - & 3 & - & - & - & - & 3 \\
\hline M75 & 1 & $?$ & - & $\mathrm{F}$ & 2 & 2 & - & - & - & - & - & - & 1 & 1 & - & - & - & 1 \\
\hline M76 & 1 & $?$ & $J$ & $\mathrm{~F}$ & 2 & 1 & - & - & - & 1 & - & - & 2 & - & - & - & - & 2 \\
\hline M81 & C & $?$ & - & $?$ & 1 & 1 & - & - & - & - & - & - & 1 & - & - & - & - & 0 \\
\hline M82 & 1 & M & $A$ & M & 4 & 1 & 1 & - & - & 2 & - & - & 4 & - & - & - & - & 4 \\
\hline M83 & 1 & $?$ & - & M & 4 & 1 & 2 & 1 & - & - & - & - & 4 & - & - & - & - & 0 \\
\hline M84 & 1 & $?$ & $\mathrm{~J}$ & $\mathrm{~F}$ & 3 & 2 & 1 & - & - & - & - & - & 3 & - & - & - & - & 3 \\
\hline M85 & C & $?$ & - & $\mathrm{F}$ & 3 & 1 & 1 & - & - & 1 & - & - & 3 & - & - & - & - & 3 \\
\hline M86 & 1 & $?$ & - & $F$ & 1 & 1 & - & - & - & - & - & - & 1 & - & - & - & - & 1 \\
\hline M91 & 1 & $M$ & $\mathrm{~J}$ & W & 2 & - & - & - & - & 2 & - & - & 2 & - & - & - & - & 2 \\
\hline M92 & 1 & $F$ & - & $\mathrm{F}$ & 2 & 1 & 1 & - & - & - & - & - & 2 & - & - & - & - & 2 \\
\hline M93 & 1 & $?+M$ & $J+A$ & D & 2 & 2 & - & - & - & - & - & - & 2 & - & - & - & - & 2 \\
\hline M94 & 1 & $?$ & - & $?$ & 1 & - & - & - & - & 1 & - & - & 1 & - & - & - & - & 0 \\
\hline M95 & 1 & $\mathrm{M}$ & - & W & 3 & 2 & 1 & - & - & - & - & - & 3 & - & - & - & - & 3 \\
\hline M100 & 1 & $\mathrm{~F}$ & $A$ & $\mathrm{~F}$ & 5 & 1 & 1 & 1 & - & - & 1 & - & 5 & - & - & - & - & 5 \\
\hline M101 & 1 & $\mathrm{M}$ & $A$ & W & 5 & 1 & 4 & - & - & - & - & - & 4 & 1 & - & - & - & 5 \\
\hline M104 & I & $F$ & $A$ & $\mathrm{~F}$ & 4 & - & - & - & - & - & 1 & 3 & 4 & - & - & - & - & 4 \\
\hline M105 & 1 & $?$ & $M$ & $M$ & 1 & 1 & - & - & - & - & - & - & 1 & - & - & - & - & 1 \\
\hline M107 & 1 & $\mathrm{M}$ & $A$ & W & 1 & 1 & - & - & - & - & - & - & 1 & - & - & - & - & 1 \\
\hline M109 & 1 & $?$ & $A$ & $?$ & 1 & 1 & - & - & - & - & - & - & 1 & - & - & - & - & 1 \\
\hline M110 & 1 & $?$ & 1 & $\mathrm{Ch}$ & 2 & 1 & 1 & - & - & - & - & - & 2 & - & - & - & - & 2 \\
\hline M111 & 1 & $?$ & $\mathrm{~J}$ & $?$ & 6 & 2 & 1 & 1 & - & - & - & 2 & 5 & - & - & - & 1 & 5 \\
\hline M112 & 1 & $?$ & $\mathrm{~J}$ & $\mathrm{~F}$ & 3 & 1 & 1 & 1 & - & - & - & - & 3 & - & - & - & - & 0 \\
\hline M113 & 1 & $?$ & - & $\mathrm{F}$ & 4 & 2 & 2 & - & - & - & - & - & 4 & - & - & - & - & 4 \\
\hline M114 & 1 & $?$ & - & $?$ & 1 & 1 & - & - & - & - & - & - & 1 & - & - & - & - & 0 \\
\hline M115 & 1 & $M$ & A & $M$ & 3 & - & 1 & - & - & 2 & - & - & 3 & - & - & - & - & 3 \\
\hline M116 & 1 & $\mathrm{~F}$ & $A$ & $\mathrm{~F}$ & 2 & 1 & 1 & - & - & - & - & - & 2 & - & - & - & - & 2 \\
\hline M117 & 1 & $\mathrm{~F}$ & $\mathrm{~J}$ & $\mathrm{~F}$ & 2 & - & 1 & - & - & 1 & - & - & 2 & - & - & - & - & 2 \\
\hline M118 & 1 & $\mathrm{~F}$ & $\mathrm{~J}$ & $\mathrm{~F}$ & 2 & 1 & 1 & - & - & - & - & - & 2 & - & - & - & - & 2 \\
\hline M119 & 1 & $\mathrm{~F}$ & - & $\mathrm{F}$ & 2 & - & 1 & - & - & - & - & 1 & 2 & - & - & - & - & 0 \\
\hline M120 & 1 & $M$ & - & $M$ & 1 & - & - & - & - & - & - & 1 & 1 & - & - & - & - & 0 \\
\hline M121 & 1 & $?$ & - & $M$ & 3 & 1 & 2 & - & - & - & - & - & 3 & - & - & - & - & 3 \\
\hline M122 & C & $\mathrm{M}$ & - & W & 3 & - & 1 & - & - & 1 & - & - & 3 & - & - & - & - & 3 \\
\hline M123 & C & $?$ & - & $M$ & 1 & - & 1 & - & - & - & - & - & - & 1 & - & - & - & 0 \\
\hline M124 & 1 & $\mathrm{~F}$ & - & $\mathrm{F}$ & 4 & 2 & 2 & - & - & - & - & - & 4 & - & - & - & - & 4 \\
\hline M125 & 1 & $?$ & - & $\mathrm{F}$ & 4 & 1 & 1 & - & - & 1 & - & 1 & 4 & - & - & - & - & 4 \\
\hline M126 & 1 & $\mathrm{M}$ & A & W & 2 & 1 & 1 & - & - & - & - & - & 2 & - & - & - & - & 2 \\
\hline M127 & 1 & $?$ & - & $\mathrm{F}$ & 3 & 2 & - & 1 & - & - & - & - & 3 & - & - & - & - & 3 \\
\hline M128 & 1 & $\mathrm{M}$ & A & $M$ & 1 & - & 1 & - & - & - & - & - & 1 & - & - & - & - & 0 \\
\hline M129 & 1 & $\mathrm{~F}+?$ & $\mathrm{~J}+\mathrm{I}$ & D & 2 & - & - & 1 & - & 1 & - & - & 2 & - & - & - & - & 2 \\
\hline M130 & C & $?$ & - & W & 5 & 1 & 4 & - & - & - & - & - & 5 & - & - & - & - & 5 \\
\hline M131 & $C$ & $?$ & - & $F$ & 2 & - & 1 & - & - & 1 & - & - & 1 & - & 1 & - & - & 2 \\
\hline M132 & 1 & ? & - & $M$ & 1 & - & - & - & - & - & - & 1 & 1 & - & - & - & - & 0 \\
\hline
\end{tabular}


Tab. 2. Continuation.

\begin{tabular}{|c|c|c|c|c|c|c|c|c|c|c|c|c|c|c|c|c|c|c|}
\hline \multirow{3}{*}{ Grave } & \multicolumn{5}{|c|}{ 1.part } & \multicolumn{7}{|c|}{ 2.part } & \multicolumn{6}{|c|}{ 3. part } \\
\hline & \multicolumn{5}{|c|}{ Attributes of burial rite } & \multicolumn{7}{|c|}{ Count of pottery types } & \multicolumn{6}{|c|}{ Pottery function } \\
\hline & B.r. & Sex & Age & Cat. & NPI & Bot. & Bow. & $P$ & V & T & MnV & $?$ & C & $\mathrm{Rf}$ & Urn & Lid & $?$ & NSC \\
\hline M133 & 1 & $\mathrm{~F}$ & - & $\mathrm{F}$ & 2 & 2 & - & - & - & - & - & - & 2 & - & - & - & - & 2 \\
\hline M134 & C & $?$ & - & $?$ & 2 & - & - & 1 & - & - & - & 1 & 2 & - & - & - & - & 0 \\
\hline M135 & 1 & $?$ & - & $\mathrm{F}$ & 1 & - & 1 & - & - & - & - & - & 1 & - & - & - & - & 0 \\
\hline M137 & C & $?$ & - & M & 2 & 1 & - & - & - & - & 1 & - & 2 & - & - & - & - & 2 \\
\hline M138 & 1 & $?$ & - & $\mathrm{F}$ & 2 & 1 & - & - & - & 1 & - & - & 2 & - & - & - & - & 2 \\
\hline M139 & C & $?$ & - & $\mathrm{F}$ & 2 & 2 & - & - & - & - & - & - & 2 & - & - & - & - & 2 \\
\hline M140 & 1 & $?$ & - & $\mathrm{F}$ & 1 & - & - & 1 & - & - & - & - & 1 & - & - & - & - & 0 \\
\hline M141 & 1 & $?$ & - & $\mathrm{F}$ & 4 & 1 & 1 & 1 & - & - & - & 1 & 2 & 2 & - & - & - & 4 \\
\hline M142 & 1 & $?$ & A & M & 2 & 2 & - & - & - & - & - & - & 2 & - & - & - & - & 0 \\
\hline M143 & C & $?$ & - & W & 1 & - & 1 & - & - & - & - & - & 1 & - & - & - & - & 0 \\
\hline M144 & C & $?$ & - & W & 4 & 1 & 2 & 1 & - & - & - & & 4 & - & - & - & - & 0 \\
\hline$\sum 101$ & \multicolumn{4}{|c|}{$82 / 19$} & 271 & 95 & 88 & 26 & 1 & 29 & 10 & 20 & 251 & 10 & 3 & 2 & 5 & 190 \\
\hline
\end{tabular}

Tab. 3. Nominal and cardinal variables of ceramic entities on cemetery Malé Kosihy. Number of vessels according to catalogue (Bujna 1995). Type (-un - unidentified) and function according to analysis of basic unit. Coordinates for $\mathrm{x}$ and y axis. PCA 1 - suitable records for analysis Example 1; PCA 2 - suitable records for analysis Example 2, f - filtered record. Morf. \& funct. means combination of morphological ( $\neq$ unidentified) and functional (= container) classification.

\begin{tabular}{|c|c|c|c|c|c|c|c|}
\hline $\begin{array}{l}\text { No. of } \\
\text { vessel }\end{array}$ & Grave & Type & Function & $X$ & Y & $\begin{array}{c}\text { PCA } \\
1\end{array}$ & $\begin{array}{c}\mathrm{PCA} \\
2\end{array}$ \\
\hline 5 & \multirow{5}{*}{1} & Bottle & container & -1 & -1 & * & * \\
\hline 6 & & Bottle & container & -2 & -1 & * & * \\
\hline 7 & & Bottle & container & -2 & 1 & * & * \\
\hline 4 & & Bowl & container & -1 & -1 & * & * \\
\hline 8 & & Pot & ritual & -3 & 2 & * & - \\
\hline 11 & \multirow{5}{*}{6} & Bowl & ritual & 0 & 1 & * & - \\
\hline 12 & & Bowl & ritual & 0 & 1 & * & - \\
\hline 13 & & Bottle & ritual & 0 & 1 & * & - \\
\hline 14 & & Bottle & ritual & 0 & 1 & * & - \\
\hline 15 & & Bottle & ritual & 0 & 1 & * & - \\
\hline 7 & \multirow{2}{*}{8} & Bowl & container & -1 & 0 & * & * \\
\hline 8 & & Bowl & ritual & -2 & 0 & * & - \\
\hline 9 & \multirow{8}{*}{9} & Miniature v. & container & 0 & -1 & * & * \\
\hline 10 & & Miniature v. & container & -1 & 1 & * & * \\
\hline 11 & & Bowl & ritual & -1 & 2 & * & - \\
\hline 12 & & Bottle & container & -1 & 2 & * & * \\
\hline 13 & & Terrine & container & -2 & 1 & * & * \\
\hline 14 & & Bottle & ritual & 1 & 4 & * & - \\
\hline 15 & & Pot & ritual & 2 & -1 & * & - \\
\hline 16 & & Miniature v. & ritual & 1 & 4 & * & - \\
\hline 1 & 12 & Bottle & $?$ & 1 & 1 & * & - \\
\hline 7 & \multirow{6}{*}{28} & Bowl & container & -2 & 0 & * & * \\
\hline 8 & & Bowl & container & -2 & 0 & * & * \\
\hline 9 & & Bowl & ritual & 1 & 0 & * & - \\
\hline 10 & & Bottle & urn & 0 & 0 & * & - \\
\hline 11 & & Bottle & ritual & -2 & -1 & * & - \\
\hline 12 & & Pot & ritual & -2 & -1 & * & - \\
\hline
\end{tabular}

\begin{tabular}{|c|c|c|c|c|c|c|c|}
\hline $\begin{array}{l}\text { No. of } \\
\text { vessel }\end{array}$ & Grave & Type & Function & $x$ & $Y$ & $\begin{array}{c}\text { PCA } \\
1\end{array}$ & $\begin{array}{c}\text { PCA } \\
2\end{array}$ \\
\hline 4 & \multirow{2}{*}{59} & Bowl & $?$ & 1 & -1 & * & - \\
\hline 5 & & Bottle & $?$ & 0 & -1 & * & - \\
\hline 12 & \multirow{6}{*}{62} & Bottle & container & -1 & -3 & * & * \\
\hline 15 & & Miniature v. & container & -1 & -2 & * & * \\
\hline 13 & & Bottle & ritual & -2 & -4 & * & - \\
\hline 14 & & Bottle & ritual & -1 & 1 & * & - \\
\hline 16 & & Pot & ritual & -2 & -3 & * & - \\
\hline 11 & & Bowl & ritual & -2 & -4 & * & - \\
\hline 3 & \multirow{2}{*}{68} & Bottle & ? & -2 & 3 & * & - \\
\hline 4 & & -un- & $?$ & -1 & 1 & * & - \\
\hline 2 & \multirow{3}{*}{83} & Bowl & container & 0 & -1 & * & * \\
\hline 1 & & Miniature v. & container & 0 & -2 & * & * \\
\hline 3 & & -un- & $?$ & 0 & 1 & * & - \\
\hline 5 & \multirow{2}{*}{84} & Bowl & ritual & 0 & 0 & * & - \\
\hline 6 & & Bottle & ritual & -1 & -1 & * & - \\
\hline 11 & \multirow{2}{*}{89} & Bottle & ritual & 0 & 0 & * & - \\
\hline 9 & & -un- & ritual & 1 & 2 & * & - \\
\hline 3 & \multirow{2}{*}{95} & Bottle & container & -1 & -2 & * & * \\
\hline 4 & & Terrine & container & -1 & -3 & * & * \\
\hline 2 & \multirow{3}{*}{103} & Terrine & $?$ & -2 & 1 & * & - \\
\hline 3 & & Bottle & $?$ & -2 & 1 & * & - \\
\hline 4 & & -un- & $?$ & -2 & 1 & * & - \\
\hline 4 & \multirow{2}{*}{109} & Miniature v. & container & -3 & 0 & * & * \\
\hline 5 & & Bottle & container & -3 & -1 & * & * \\
\hline 1 & 120 & Bowl & $?$ & 0 & -2 & * & - \\
\hline 1 & \multirow{2}{*}{133} & Bottle & ritual & -1 & 2 & * & - \\
\hline 2 & & Bottle & ritual & -1 & 1 & * & - \\
\hline
\end{tabular}


Tab. 3. Continuation.

\begin{tabular}{|c|c|c|c|c|c|c|c|c|c|c|c|c|c|c|c|}
\hline $\begin{array}{l}\text { No. of } \\
\text { vessel }\end{array}$ & Grave & Type & Function & $x$ & $\mathrm{Y}$ & $\begin{array}{c}\text { PCA } \\
1\end{array}$ & $\begin{array}{c}\text { PCA } \\
2\end{array}$ & $\begin{array}{l}\text { No. of } \\
\text { vessel }\end{array}$ & Grave & Type & Function & $x$ & $\mathrm{Y}$ & $\begin{array}{c}\mathrm{PCA} \\
1\end{array}$ & $\begin{array}{c}\text { PCA } \\
2\end{array}$ \\
\hline 6 & \multirow{3}{*}{142} & Bowl & ritual & 1 & -1 & * & - & 15 & \multirow{7}{*}{217} & Bowl & ritual & -2 & -2 & * & - \\
\hline 7 & & Bottle & ritual & -1 & -1 & * & - & 16 & & Pot & container & 1 & 1 & * & * \\
\hline 8 & & Bottle & ritual & 1 & -1 & * & - & 17 & & Miniature v. & container & 0 & 0 & * & * \\
\hline 28 & \multirow{5}{*}{149} & Bowl & container & 1 & 1 & * & * & 18 & & Bowl & ritual & 0 & -5 & * & - \\
\hline 29 & & Bowl & container & 2 & -1 & * & * & 19 & & Bowl & ritual & 0 & -3 & * & - \\
\hline 30 & & Terrine & container & 2 & -1 & * & * & 20 & & Bowl & ritual & 1 & -1 & * & - \\
\hline 31 & & Miniature v. & container & 2 & -2 & * & * & 21 & & Bottle & ritual & -1 & -2 & * & - \\
\hline 32 & & Bottle & container & 2 & -2 & * & * & 1 & \multirow{2}{*}{221} & Bowl & ritual & 1 & -2 & * & - \\
\hline 2 & \multirow{2}{*}{153} & Bowl & container & 2 & -1 & * & * & 2 & & Bottle & ritual & 1 & -2 & * & - \\
\hline 3 & & Bottle & ritual & 1 & -1 & * & - & 4 & \multirow{2}{*}{222} & Bowl & ritual & 0 & -1 & * & - \\
\hline 2 & 166 & Miniature v. & container & -1 & 2 & * & * & 5 & & Bottle & $?$ & -1 & -1 & * & - \\
\hline 10 & \multirow{5}{*}{168} & Bowl & ritual & -2 & -2 & * & - & 6 & \multirow{3}{*}{227} & Bowl & container & 0 & 1 & * & * \\
\hline 11 & & Terrine & ritual & 1 & 0 & * & - & 7 & & -un- & container & -1 & 1 & * & * \\
\hline 12 & & Bottle & ritual & 1 & 2 & * & - & 8 & & Bottle & container & 0 & 2 & * & * \\
\hline 13 & & Miniature v. & container & 0 & 2 & * & * & 8 & \multirow{3}{*}{234} & Pot & ritual & -1 & -3 & * & - \\
\hline 14 & & Miniature v. & container & 0 & 0 & * & * & 7 & & Bowl & container & -1 & 0 & * & * \\
\hline 1 & 171 & Bowl & ritual & -1 & 0 & * & - & 9 & & -un- & $?$ & 0 & 0 & * & - \\
\hline 16 & \multirow{3}{*}{176} & Bowl & container & -1 & -1 & * & * & 7 & \multirow{4}{*}{235} & Bottle & ritual & 0 & 0 & * & - \\
\hline 17 & & Terrine & container & -1 & -2 & * & * & 5 & & Bottle & container & -2 & -3 & * & * \\
\hline 19 & & Bottle & container & -2 & -2 & * & * & 6 & & Bowl & ritual & 0 & -2 & * & - \\
\hline 16 & \multirow{3}{*}{180} & Bowl & $?$ & -1 & -4 & * & - & 8 & & Bowl & ritual & -1 & -2 & * & - \\
\hline 17 & & Bowl & container & -1 & 1 & * & * & 10 & \multirow{6}{*}{248} & Bowl & container & 0 & -1 & * & * \\
\hline 18 & & Bottle & $?$ & 0 & -2 & * & - & 11 & & Terrine & container & 1 & -2 & * & * \\
\hline 12 & \multirow{4}{*}{182} & Bowl & container & -1 & 4 & * & * & 12 & & Bottle & ritual & 2 & -1 & * & - \\
\hline 13 & & Bowl & container & -1 & -2 & * & * & 13 & & Bottle & ritual & 0 & 0 & * & - \\
\hline 14 & & Pot & container & 1 & 4 & * & * & 14 & & -un- & ritual & 0 & 0 & * & - \\
\hline 15 & & Bottle & container & -1 & -4 & * & * & 15 & & Bowl & ritual & -1 & 0 & $*$ & - \\
\hline 2 & \multirow{2}{*}{183} & Bottle & ritual & 0 & 2 & * & - & 2 & \multirow{2}{*}{249} & Bowl & container & -2 & -1 & * & * \\
\hline 3 & & Bowl & ritual & 0 & 0 & * & - & 3 & & -un- & ritual & -2 & 0 & * & - \\
\hline 2 & 188 & Bowl & $?$ & 1 & 1 & * & - & 14 & & Bowl & container & -3 & 0 & * & * \\
\hline 3 & \multirow{2}{*}{189} & Bowl & container & 1 & 1 & * & * & 15 & 271 & Bowl & container & -3 & -4 & * & * \\
\hline 4 & & Bottle & container & 2 & 1 & * & * & 16 & 217 & Bowl & container & -3 & -3 & * & * \\
\hline 11 & & Bowl & container & 1 & 0 & * & * & 17 & & Bottle & ritual & -1 & -3 & * & - \\
\hline 12 & & Bottle & container & 0 & -1 & * & * & 3 & & Bottle & $?$ & 0 & 0 & * & - \\
\hline 13 & 102 & Bottle & ritual & 0 & 0 & * & - & 4 & & Bottle & $?$ & 0 & 0 & * & - \\
\hline 14 & Tr & -un- & ritual & -1 & 0 & * & - & 5 & 283 & Bowl & $?$ & 0 & 0 & * & - \\
\hline 15 & & Bottle & ritual & -1 & 1 & * & - & 8 & & Bottle & container & 0 & 1 & $*$ & * \\
\hline 16 & & Terrine & ritual & -1 & -1 & * & - & 9 & & Bowl & container & 0 & 2 & * & * \\
\hline 1 & 197 & Bottle & ritual & -1 & 0 & * & - & 2 & & Bowl & ritual & 0 & 0 & * & - \\
\hline 1 & 204 & -un- & $?$ & -1 & 0 & * & - & 3 & 200 & Pot & container & 3 & 0 & * & * \\
\hline 4 & & Miniature v. & container & 0 & -2 & * & * & 4 & & Bowl & container & 1 & 1 & * & * \\
\hline 5 & 216 & Terrine & $?$ & 0 & -4 & * & - & 5 & ק0 & Bottle & container & 1 & -1 & * & * \\
\hline 6 & & Bottle & $?$ & 0 & -3 & * & - & 6 & 298 & Bowl & lid & 1 & -1 & * & - \\
\hline 10 & & Bottle & container & -3 & -4 & * & * & 7 & & Pot & ritual & 1 & -1 & * & - \\
\hline 11 & & Bottle & container & -2 & -4 & * & * & 11 & 307 & Bowl & container & 1 & -4 & * & * \\
\hline 12 & 217 & Bottle & container & -3 & -3 & $*$ & $*$ & 3 & 316 & Terrine & ritual & -1 & 4 & * & - \\
\hline 13 & & Miniature v. & container & -2 & -3 & * & * & 9 & 330 & Bowl & lid & 1 & -4 & * & - \\
\hline 14 & & Miniature v. & ritual & -1 & -2 & $*$ & - & 10 & 300 & Terrine & container & 1 & -4 & * & * \\
\hline
\end{tabular}


Tab. 3. Continuation.

\begin{tabular}{|c|c|c|c|c|c|c|c|}
\hline $\begin{array}{l}\text { No. of } \\
\text { vessel }\end{array}$ & Grave & Type & Function & $X$ & Y & $\begin{array}{c}\text { PCA } \\
1\end{array}$ & $\begin{array}{c}\text { PCA } \\
2\end{array}$ \\
\hline 19 & \multirow{5}{*}{331} & Bowl & container & -1 & -4 & * & * \\
\hline 20 & & Bowl & container & -1 & -4 & * & * \\
\hline 21 & & Pot & container & 0 & -4 & * & * \\
\hline 22 & & Bottle & container & 0 & -5 & * & $f$ \\
\hline 23 & & Bottle & container & -1 & -5 & * & * \\
\hline 8 & \multirow{2}{*}{335} & Bowl & lid & 1 & -4 & * & - \\
\hline 9 & & Bottle & container & 1 & -4 & * & * \\
\hline 1 & 345 & Bottle & $?$ & 0 & 0 & * & - \\
\hline 9 & \multirow{2}{*}{346} & Bowl & ritual & 1 & -1 & * & - \\
\hline 10 & & Bowl & ritual & 1 & -2 & * & - \\
\hline 5 & \multirow{4}{*}{356} & Bowl & ritual & 1 & 0 & * & - \\
\hline 6 & & Terrine & container & 1 & -4 & * & * \\
\hline 7 & & Bottle & container & -1 & -4 & * & * \\
\hline 8 & & -un- & $?$ & 1 & -4 & * & - \\
\hline 1 & 357 & -un- & $?$ & 1 & -1 & * & - \\
\hline 5 & \multirow{3}{*}{394} & Bowl & container & 1 & 4 & * & * \\
\hline 6 & & Miniature v. & ritual & 2 & -5 & * & - \\
\hline 7 & & -un- & ritual & 2 & -5 & * & - \\
\hline 3 & \multirow{2}{*}{395} & Bowl & container & -1 & 2 & * & * \\
\hline 4 & & Vase & ritual & -1 & 1 & * & - \\
\hline 10 & \multirow{2}{*}{396} & Bowl & container & -1 & 4 & * & * \\
\hline 11 & & Bottle & container & -1 & 3 & * & * \\
\hline 12 & \multirow{3}{*}{425} & Terrine & container & 1 & -1 & * & * \\
\hline 13 & & -un- & $?$ & 1 & 0 & * & - \\
\hline 14 & & -un- & $?$ & 1 & 1 & * & - \\
\hline 2 & \multirow{3}{*}{431} & Bowl & container & 0 & -4 & * & * \\
\hline 3 & & -un- & ritual & 0 & -3 & * & - \\
\hline 4 & & -un- & ritual & 0 & 0 & * & - \\
\hline 17 & \multirow{8}{*}{437} & Bottle & container & 0 & -2 & * & * \\
\hline 23 & & Pot & ritual & 0 & 0 & * & - \\
\hline 13 & & Bowl & container & 2 & -2 & * & * \\
\hline 14 & & Bowl & container & 2 & -2 & * & * \\
\hline 15 & & Bowl & container & 2 & -1 & * & * \\
\hline 16 & & Terrine & container & -1 & -2 & * & * \\
\hline 18 & & Pot & ritual & 0 & -2 & * & - \\
\hline 28 & & Bowl & container & -2 & -1 & * & * \\
\hline 8 & \multirow{3}{*}{448} & Bowl & container & 0 & 1 & * & * \\
\hline 9 & & Bottle & ritual & 0 & 3 & $f$ & - \\
\hline 10 & & Bottle & ritual & -1 & -1 & * & - \\
\hline 10 & \multirow{3}{*}{452} & Bottle & ritual & 0 & 0 & * & - \\
\hline 11 & & Bottle & ritual & 1 & 1 & * & - \\
\hline 12 & & Bottle & ritual & 1 & 1 & * & - \\
\hline 23 & \multirow{4}{*}{453} & Bowl & container & -2 & 1 & * & * \\
\hline 24 & & Bowl & ritual & -3 & -2 & * & - \\
\hline 25 & & Bottle & container & 0 & -2 & * & * \\
\hline 26 & & Terrine & ritual & -3 & 1 & * & - \\
\hline 3 & \multirow{3}{*}{459} & Bowl & container & 0 & -1 & * & $*$ \\
\hline 4 & & Miniature v. & container & 1 & 2 & * & $f$ \\
\hline 5 & & Bottle & container & 0 & 2 & * & * \\
\hline
\end{tabular}

\begin{tabular}{|c|c|c|c|c|c|c|c|}
\hline $\begin{array}{l}\text { No. of } \\
\text { vessel }\end{array}$ & Grave & Type & Function & $x$ & $Y$ & $\begin{array}{c}\text { PCA } \\
1\end{array}$ & $\begin{array}{c}\mathrm{PCA} \\
2\end{array}$ \\
\hline 6 & 468 & Bowl & ritual & 0 & -2 & * & - \\
\hline 1 & 469 & Bowl & container & 1 & 3 & $f$ & $f$ \\
\hline 3 & & Bottle & container & -1 & -4 & * & * \\
\hline 4 & 470 & Bowl & lid & -1 & -4 & * & - \\
\hline 1 & & Bowl & container & -1 & 3 & * & * \\
\hline 2 & 175 & Pot & container & 1 & 0 & * & * \\
\hline 3 & 475 & Miniature v. & container & -1 & 0 & * & * \\
\hline 4 & & Bottle & container & 1 & -3 & * & * \\
\hline 8 & & Bowl & ritual & -2 & -1 & * & - \\
\hline 10 & & -un- & ritual & -2 & -3 & * & - \\
\hline 9 & 477 & Bottle & container & 0 & 1 & * & * \\
\hline 12 & & -un- & ritual & 1 & 1 & * & - \\
\hline 11 & & Pot & ritual & -1 & -4 & * & - \\
\hline 6 & & Bowl & container & 0 & -2 & * & * \\
\hline 7 & 482 & Terrine & ritual & 1 & -4 & * & - \\
\hline 8 & & Bottle & container & -1 & -3 & * & * \\
\hline 14 & & Bottle & ritual & 0 & 5 & * & - \\
\hline 10 & & Bowl & ritual & -1 & -1 & * & - \\
\hline 9 & & Bowl & ritual & -1 & 4 & * & - \\
\hline 13 & & Bottle & ritual & 2 & -1 & * & - \\
\hline 7 & 400 & Bowl & container & -1 & 1 & * & * \\
\hline 8 & & Bowl & ritual & -1 & 4 & * & - \\
\hline 11 & & Bottle & container & -1 & 3 & * & * \\
\hline 12 & & Bottle & container & 0 & 2 & * & * \\
\hline 2 & & Bowl & container & -1 & -1 & * & * \\
\hline 3 & 485 & Bowl & container & -1 & -2 & * & * \\
\hline 4 & & Bottle & container & 0 & -1 & * & * \\
\hline 7 & 488 & Bottle & ritual & 0 & 0 & * & - \\
\hline 1 & & Miniature v. & container & -2 & 0 & * & * \\
\hline 2 & 495 & Terrine & container & -1 & 0 & * & * \\
\hline 3 & & Bowl & ritual & -1 & -1 & * & - \\
\hline 9 & & Bowl & ritual & 0 & -5 & * & - \\
\hline 10 & & Bowl & ritual & 0 & -5 & * & - \\
\hline 11 & & Bottle & ritual & 0 & -5 & * & - \\
\hline 12 & 500 & Bottle & ritual & 0 & -5 & * & - \\
\hline 13 & & Bottle & ritual & 1 & -5 & * & - \\
\hline 14 & & Bottle & ritual & 0 & -5 & * & - \\
\hline 15 & & Bottle & container & 0 & 1 & * & * \\
\hline 16 & & Bowl & lid & 0 & 1 & * & - \\
\hline 4 & & Bowl & container & -1 & 0 & * & * \\
\hline 7 & 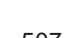 & Bottle & ritual & -1 & -3 & * & - \\
\hline 5 & & Pot & container & 1 & 4 & * & * \\
\hline 6 & & Miniature v. & container & 1 & 0 & * & * \\
\hline 4 & & Terrine & urn & 0 & 1 & * & - \\
\hline 3 & 500 & Bottle & container & 1 & 1 & * & * \\
\hline 5 & & Bowl & lid & 1 & 1 & * & - \\
\hline 6 & & -un- & ritual & -1 & -4 & * & - \\
\hline 5 & $20-$ & Bowl & $?$ & 0 & -2 & * & - \\
\hline 7 & & Bottle & $?$ & 1 & 5 & * & - \\
\hline$\sum 248$ & 78 & \multicolumn{3}{|c|}{ morf. \& funct. class $=209$} & $\Sigma$ & 246 & 110 \\
\hline
\end{tabular}


Tab. 4. Nominal and cardinal variables of ceramic entities on cemetery Maňa. Number of vessels according to catalogue (Benadik 1983). Type and function according to analysis of basic unit. Coordinates for $\mathrm{x}$ and y axis. PCA 1 - suitable records for statistical analysis. Morf. \& funct. - combination of morphological ( $\neq$ unidentified) and functional (= container) classification.

\begin{tabular}{|c|c|c|c|c|c|c|}
\hline $\begin{array}{l}\text { No. of } \\
\text { vessel }\end{array}$ & Grave & Type & Function & $x$ & $Y$ & PCA 1 \\
\hline 5 & \multirow{3}{*}{3} & Bowl & container & -2 & 3 & * \\
\hline 6 & & Bowl & container & -1 & 2 & * \\
\hline 7 & & Bottle & container & -2 & -1 & * \\
\hline 8 & \multirow{3}{*}{10} & Bowl & lid & -1 & 3 & - \\
\hline 9 & & Terrine & container & -1 & 3 & $*$ \\
\hline 10 & & Bottle & container & -2 & -4 & * \\
\hline 21 & 13 & Bowl & container & -1 & 0 & * \\
\hline 12 & \multirow{5}{*}{14} & Bottle & container & 3 & 5 & * \\
\hline 13 & & Bottle & container & 3 & 2 & * \\
\hline 14 & & Terrine & container & 3 & 4 & * \\
\hline 15 & & Bowl & container & 3 & -3 & * \\
\hline 16 & & Pot & container & 3 & -5 & * \\
\hline 11 & \multirow{3}{*}{15} & Bowl & container & -2 & -1 & * \\
\hline 12 & & Bottle & container & -2 & -3 & * \\
\hline 13 & & Bowl & container & -2 & 0 & * \\
\hline 12 & \multirow{4}{*}{16} & Bowl & container & -2 & -4 & * \\
\hline 13 & & Bottle & container & -2 & -3 & * \\
\hline 14 & & Bottle & container & -2 & 4 & * \\
\hline 15 & & Bottle & container & -2 & -3 & * \\
\hline 1 & \multirow{3}{*}{19} & Bowl & container & -1 & -4 & * \\
\hline 2 & & Bottle & container & -2 & -3 & * \\
\hline 3 & & Bottle & container & -3 & -4 & * \\
\hline 4 & \multirow{3}{*}{20} & Bowl & container & 0 & -3 & * \\
\hline 6 & & Bottle & container & 0 & -4 & * \\
\hline 5 & & Bottle & container & 1 & -4 & * \\
\hline 2 & \multirow{2}{*}{21} & Bottle & container & -1 & -4 & * \\
\hline 3 & & -un- & $?$ & -1 & -4 & - \\
\hline 2 & \multirow{2}{*}{23} & Bottle & container & -2 & -3 & * \\
\hline 3 & & Bowl & container & -2 & -2 & * \\
\hline 1 & \multirow{2}{*}{24} & Terrine & container & -1 & 1 & * \\
\hline 2 & & Miniature v. & container & 0 & -2 & * \\
\hline 9 & \multirow{3}{*}{27} & Bottle & container & 1 & 0 & * \\
\hline 10 & & Bottle & container & -1 & 4 & * \\
\hline 11 & & Terrine & container & 1 & -1 & * \\
\hline 8 & \multirow{5}{*}{28} & Terrine & container & 1 & -5 & * \\
\hline 9 & & Bottle & container & 1 & -4 & * \\
\hline 10 & & Bowl & container & 0 & -5 & * \\
\hline 8 & & Bowl & container & -1 & -3 & * \\
\hline 9 & & Bottle & container & -1 & -1 & * \\
\hline 3 & \multirow{3}{*}{30} & Bottle & container & -1 & -1 & * \\
\hline 4 & & Vase & container & -1 & -5 & * \\
\hline 5 & & Bowl & container & -1 & -5 & * \\
\hline 1 & \multirow{3}{*}{32} & Terrine & urn & 0 & 0 & - \\
\hline 7 & & Bowl & lid & 0 & 0 & - \\
\hline 8 & & Bowl & container & 0 & -1 & * \\
\hline 11 & 35 & Bottle & container & -1 & -4 & * \\
\hline 8 & 36 & Bottle & container & -1 & -2 & * \\
\hline
\end{tabular}

\begin{tabular}{|c|c|c|c|c|c|c|}
\hline $\begin{array}{l}\text { No. of } \\
\text { vessel }\end{array}$ & Grave & Type & Function & $\mathrm{X}$ & $\mathrm{Y}$ & PCA 1 \\
\hline 7 & \multirow{3}{*}{38} & Bowl & container & -1 & 3 & * \\
\hline 2 & & Bowl & container & -1 & 4 & * \\
\hline 3 & & Bottle & container & -1 & -4 & * \\
\hline 1 & \multirow{3}{*}{39} & Bowl & container & -1 & -3 & * \\
\hline 12 & & Bottle & container & -1 & 4 & * \\
\hline 13 & & Bottle & container & 1 & -5 & * \\
\hline 14 & \multirow{3}{*}{40} & Bottle & container & -2 & 3 & * \\
\hline 12 & & Bowl & container & -1 & 4 & * \\
\hline 13 & & Bowl & container & -1 & 3 & * \\
\hline 4 & \multirow{3}{*}{43} & Bottle & container & -1 & 3 & * \\
\hline 8 & & Bottle & container & -1 & 1 & * \\
\hline 9 & & Bowl & container & -1 & 0 & * \\
\hline 1 & \multirow{2}{*}{53} & Terrine & container & 1 & 3 & * \\
\hline 8 & & Miniature v. & container & 1 & 4 & * \\
\hline 10 & \multirow{4}{*}{59} & Pot & container & -1 & 4 & * \\
\hline 8 & & Pot & container & -2 & -3 & * \\
\hline 9 & & Bottle & container & -2 & -4 & * \\
\hline 10 & & Bowl & container & -1 & 3 & * \\
\hline 11 & \multirow{3}{*}{60} & Bottle & container & -2 & -3 & * \\
\hline 6 & & Bowl & container & -1 & -4 & * \\
\hline 7 & & Bowl & container & -2 & 5 & * \\
\hline 8 & \multirow{3}{*}{61} & Bowl & container & -2 & 2 & * \\
\hline 10 & & Bowl & container & -2 & 1 & * \\
\hline 11 & & Terrine & container & -2 & -4 & * \\
\hline 12 & \multirow{4}{*}{62} & Bowl & container & -1 & 3 & * \\
\hline 10 & & Bowl & container & -1 & 2 & * \\
\hline 11 & & Bottle & container & -2 & -4 & * \\
\hline 12 & & Bottle & container & -1 & -4 & * \\
\hline 8 & \multirow{7}{*}{64} & Bottle & container & -3 & -5 & * \\
\hline 11 & & Terrine & container & -1 & -4 & * \\
\hline 12 & & Terrine & container & -3 & -5 & * \\
\hline 13 & & Bowl & container & -2 & -4 & * \\
\hline 14 & & Bottle & container & -1 & -5 & * \\
\hline 15 & & Bowl & container & -2 & 3 & * \\
\hline 16 & & Bowl & container & -2 & 4 & * \\
\hline 17 & 66 & Pot & container & 1 & -2 & * \\
\hline 1 & \multirow{2}{*}{68} & Bottle & container & -1 & -2 & * \\
\hline 7 & & Bottle & container & 0 & -3 & * \\
\hline 8 & \multirow{2}{*}{69} & Bottle & container & 0 & 5 & * \\
\hline 5 & & Bowl & ritual & 3 & 4 & - \\
\hline 6 & \multirow{3}{*}{73} & Terrine & container & -2 & 0 & * \\
\hline 5 & & Terrine & container & -2 & -1 & * \\
\hline 6 & & Terrine & container & -2 & -2 & * \\
\hline 4 & 75 & Bottle & container & -1 & -4 & * \\
\hline 5 & \multirow{2}{*}{76} & Bottle & container & -1 & -2 & * \\
\hline 2 & & Terrine & container & -2 & -1 & * \\
\hline 1 & 82 & Terrine & container & -1 & -1 & * \\
\hline
\end{tabular}


Table 4. Continuation.

\begin{tabular}{|c|c|c|c|c|c|c|}
\hline $\begin{array}{l}\text { No. of } \\
\text { vessel }\end{array}$ & Grave & Type & Function & $x$ & $\mathrm{Y}$ & PCA 1 \\
\hline 6 & \multirow{3}{*}{82} & Bottle & container & -1 & -3 & * \\
\hline 7 & & Terrine & container & -1 & -4 & * \\
\hline 8 & & Bowl & container & -1 & 3 & * \\
\hline 5 & \multirow{3}{*}{84} & Bowl & container & -2 & -1 & * \\
\hline 3 & & Bottle & container & -3 & -3 & * \\
\hline 4 & & Bottle & container & -3 & -4 & * \\
\hline 5 & \multirow{3}{*}{85} & Terrine & container & 1 & 2 & * \\
\hline 4 & & Bottle & container & 0 & 1 & * \\
\hline 5 & & Bowl & container & -1 & 3 & * \\
\hline 6 & 86 & Bottle & container & -1 & -1 & * \\
\hline 5 & \multirow{2}{*}{91} & Terrine & container & -1 & 1 & * \\
\hline 10 & & Terrine & container & -1 & 0 & * \\
\hline 11 & \multirow{2}{*}{92} & Bowl & container & -2 & -3 & * \\
\hline 8 & & Bottle & container & -2 & -4 & * \\
\hline 9 & \multirow{2}{*}{93} & Bottle & container & -1 & 3 & * \\
\hline 6 & & Bottle & container & -1 & -4 & * \\
\hline 1 & \multirow{3}{*}{95} & Bottle & container & -2 & -3 & * \\
\hline 7 & & Bottle & container & -3 & -4 & * \\
\hline 8 & & Bowl & container & -1 & -4 & * \\
\hline 9 & \multirow{4}{*}{100} & Pot & container & -1 & -1 & * \\
\hline 17 & & Bottle & container & -1 & 5 & * \\
\hline 18 & & Bowl & container & 0 & 5 & * \\
\hline 20 & & Miniature v. & container & 1 & 4 & * \\
\hline 21 & \multirow{5}{*}{101} & Bowl & container & -1 & 0 & * \\
\hline 10 & & Bottle & container & -2 & 2 & * \\
\hline 11 & & Bowl & container & -1 & 3 & * \\
\hline 12 & & Bowl & ritual & 0 & 3 & - \\
\hline 13 & & Bowl & container & 0 & 4 & * \\
\hline 14 & \multirow{4}{*}{104} & Miniature v. & container & -1 & 2 & * \\
\hline 11 & & -un- & container & -1 & 1 & * \\
\hline 12 & & -un- & container & -1 & 0 & * \\
\hline 13 & & -un- & container & -2 & -5 & * \\
\hline 14 & 105 & Bottle & container & -1 & -5 & * \\
\hline 4 & 107 & Bottle & container & -2 & -4 & * \\
\hline 9 & 109 & Bottle & container & 1 & 4 & * \\
\hline 2 & \multirow{2}{*}{110} & Bowl & container & -1 & 3 & * \\
\hline 5 & & Bottle & container & -1 & -4 & * \\
\hline 6 & \multirow{5}{*}{111} & Bottle & container & -3 & -4 & * \\
\hline 6 & & Bottle & container & -3 & -3 & * \\
\hline 7 & & Pot & container & -2 & -3 & * \\
\hline 8 & & Bowl & container & -2 & -2 & * \\
\hline 9 & & -un- & container & -1 & 0 & * \\
\hline 7 & \multirow{4}{*}{113} & Bottle & container & -3 & -4 & * \\
\hline 12 & & Bowl & container & -2 & -3 & * \\
\hline 13 & & Bottle & container & -3 & -3 & * \\
\hline 14 & & Bowl & container & -2 & -2 & * \\
\hline 1 & \multirow{2}{*}{115} & Terrine & container & -2 & -4 & * \\
\hline 3 & & Terrine & container & -2 & -1 & * \\
\hline
\end{tabular}

\begin{tabular}{|c|c|c|c|c|c|c|}
\hline $\begin{array}{l}\text { No. of } \\
\text { vessel }\end{array}$ & Grave & Type & Function & $x$ & $\mathrm{Y}$ & PCA 1 \\
\hline 4 & 115 & Bowl & container & -1 & 3 & * \\
\hline $\begin{array}{l}5 \\
5\end{array}$ & 116 & $\begin{array}{l}\text { Bottle } \\
\text { Bowl }\end{array}$ & $\begin{array}{l}\text { container } \\
\text { container }\end{array}$ & $\begin{array}{l}-1 \\
-1\end{array}$ & $\begin{array}{l}-3 \\
-4\end{array}$ & * \\
\hline $\begin{array}{l}6 \\
1\end{array}$ & 117 & $\begin{array}{l}\text { Bowl } \\
\text { Terrine }\end{array}$ & $\begin{array}{l}\text { container } \\
\text { container }\end{array}$ & $\begin{array}{l}-1 \\
-1\end{array}$ & $\begin{array}{l}-3 \\
-4\end{array}$ & * \\
\hline $\begin{array}{l}2 \\
7\end{array}$ & 118 & $\begin{array}{l}\text { Bowl } \\
\text { Bottle }\end{array}$ & $\begin{array}{l}\text { container } \\
\text { container }\end{array}$ & $\begin{array}{l}-1 \\
-1\end{array}$ & $\begin{array}{l}3 \\
0\end{array}$ & * \\
\hline $\begin{array}{l}9 \\
2 \\
3\end{array}$ & 121 & $\begin{array}{l}\text { Bowl } \\
\text { Bowl } \\
\text { Bottle }\end{array}$ & $\begin{array}{l}\text { container } \\
\text { container } \\
\text { container }\end{array}$ & $\begin{array}{l}0 \\
-1 \\
-1\end{array}$ & $\begin{array}{l}-4 \\
-4 \\
-4\end{array}$ & $\begin{array}{l}* \\
* \\
*\end{array}$ \\
\hline $\begin{array}{l}4 \\
7 \\
8\end{array}$ & 122 & $\begin{array}{l}\text { Bowl } \\
\text { Terrine } \\
\text { Vase }\end{array}$ & $\begin{array}{l}\text { container } \\
\text { container } \\
\text { container }\end{array}$ & $\begin{array}{l}1 \\
-1 \\
0\end{array}$ & $\begin{array}{l}-3 \\
-3 \\
-4\end{array}$ & $\begin{array}{l}* \\
* \\
*\end{array}$ \\
\hline $\begin{array}{c}8 \\
26 \\
27 \\
28\end{array}$ & 124 & $\begin{array}{l}\text { Bottle } \\
\text { Bowl } \\
\text { Bottle } \\
\text { Bowl }\end{array}$ & $\begin{array}{l}\text { container } \\
\text { container } \\
\text { container } \\
\text { container }\end{array}$ & $\begin{array}{l}-2 \\
-1 \\
-1 \\
-1\end{array}$ & $\begin{array}{l}3 \\
2 \\
-3 \\
4\end{array}$ & $\begin{array}{l}* \\
* \\
* \\
*\end{array}$ \\
\hline $\begin{array}{l}29 \\
25 \\
26 \\
27\end{array}$ & 125 & $\begin{array}{l}\text { Bottle } \\
\text { Terrine } \\
\text { Bowl } \\
\text {-un- }\end{array}$ & $\begin{array}{l}\text { container } \\
\text { container } \\
\text { container } \\
\text { container }\end{array}$ & $\begin{array}{l}-2 \\
-2 \\
-1 \\
-1\end{array}$ & $\begin{array}{l}4 \\
-2 \\
-2 \\
-3\end{array}$ & $\begin{array}{l}* \\
* \\
* \\
*\end{array}$ \\
\hline $\begin{array}{l}28 \\
13\end{array}$ & 126 & $\begin{array}{l}\text { Bottle } \\
\text { Bowl }\end{array}$ & $\begin{array}{l}\text { container } \\
\text { container }\end{array}$ & $\begin{array}{l}-2 \\
-2\end{array}$ & $\begin{array}{l}-4 \\
-2\end{array}$ & * \\
\hline $\begin{array}{c}9 \\
29 \\
30\end{array}$ & 127 & $\begin{array}{l}\text { Pot } \\
\text { Bottle } \\
\text { Bottle }\end{array}$ & $\begin{array}{l}\text { container } \\
\text { container } \\
\text { container }\end{array}$ & $\begin{array}{c}-2 \\
1 \\
1\end{array}$ & $\begin{array}{l}3 \\
-3 \\
-4\end{array}$ & $\begin{array}{l}* \\
* \\
*\end{array}$ \\
\hline $\begin{array}{r}2 \\
11\end{array}$ & 129 & $\begin{array}{l}\text { Pot } \\
\text { Terrine }\end{array}$ & $\begin{array}{l}\text { container } \\
\text { container }\end{array}$ & $\begin{array}{l}0 \\
-1\end{array}$ & $\begin{array}{l}3 \\
2\end{array}$ & * \\
\hline $\begin{array}{c}12 \\
8 \\
12 \\
11 \\
10\end{array}$ & 130 & $\begin{array}{l}\text { Bowl } \\
\text { Bottle } \\
\text { Bowl } \\
\text { Bowl } \\
\text { Bowl }\end{array}$ & $\begin{array}{l}\text { container } \\
\text { container } \\
\text { container } \\
\text { container } \\
\text { container }\end{array}$ & $\begin{array}{l}-1 \\
1 \\
-2 \\
1 \\
-1\end{array}$ & $\begin{array}{l}2 \\
3 \\
3 \\
1 \\
1\end{array}$ & $\begin{array}{l}\text { * } \\
\text { * } \\
\text { * } \\
\text { * } \\
\text { * }\end{array}$ \\
\hline $\begin{array}{l}9 \\
7\end{array}$ & 131 & $\begin{array}{l}\text { Terrine } \\
\text { Bowl }\end{array}$ & $\begin{array}{l}\text { urn } \\
\text { container }\end{array}$ & $\begin{array}{l}0 \\
1\end{array}$ & $\begin{array}{l}0 \\
0\end{array}$ & - \\
\hline $\begin{array}{c}5 \\
17\end{array}$ & 133 & $\begin{array}{l}\text { Bottle } \\
\text { Bottle }\end{array}$ & $\begin{array}{l}\text { container } \\
\text { container }\end{array}$ & $\begin{array}{l}-1 \\
-1\end{array}$ & $\begin{array}{l}2 \\
0\end{array}$ & * \\
\hline $\begin{array}{l}3 \\
5\end{array}$ & 137 & $\begin{array}{l}\text { Miniature v. } \\
\text { Bottle }\end{array}$ & $\begin{array}{l}\text { container } \\
\text { container }\end{array}$ & $\begin{array}{l}-1 \\
-1\end{array}$ & $\begin{array}{l}-1 \\
-2\end{array}$ & * \\
\hline $\begin{array}{c}6 \\
10\end{array}$ & 138 & $\begin{array}{l}\text { Terrine } \\
\text { Bottle }\end{array}$ & $\begin{array}{l}\text { container } \\
\text { container }\end{array}$ & $\begin{array}{l}-1 \\
-1\end{array}$ & $\begin{array}{c}-5 \\
4\end{array}$ & * \\
\hline $\begin{array}{l}11 \\
3\end{array}$ & 139 & $\begin{array}{l}\text { Bottle } \\
\text { Bottle }\end{array}$ & $\begin{array}{l}\text { container } \\
\text { container }\end{array}$ & $\begin{array}{l}-1 \\
-1\end{array}$ & $\begin{array}{l}0 \\
-1\end{array}$ & * \\
\hline $\begin{array}{l}4 \\
7 \\
8 \\
9\end{array}$ & 141 & $\begin{array}{l}\text { Bottle } \\
\text {-un- } \\
\text { Bowl } \\
\text { Pot }\end{array}$ & $\begin{array}{l}\text { container } \\
\text { container } \\
\text { ritual } \\
\text { ritual }\end{array}$ & $\begin{array}{l}-1 \\
-2 \\
-2 \\
-2\end{array}$ & $\begin{array}{l}4 \\
-1 \\
-2 \\
-3\end{array}$ & $\begin{array}{l}* \\
* \\
- \\
-\end{array}$ \\
\hline$\sum 189$ & 68 & \multicolumn{3}{|c|}{ morf. \& funct. class $=180$} & $\Sigma$ & 180 \\
\hline
\end{tabular}




\section{LITERATURE}

Arnold 2001

Benadik 1983

Brück 2006

Buchvaldek/Koutecký 1972

Bujna 1991

Bujna 1995

Bujna 1998

Bujna 2012a

Bujna $2012 b$

Bujna 2014

Chapman 2000

Chroustovský 2008

Demján 2012

Ďud’áková 2014

Fahlander 2003

Fusek 2005

Gramsch 2007

Hammer 2014

Härke 2014

Kaliff/Oestigaard 2004

Kaňáková/Parma 2015

Kovářová 2004

Krekovič 2007

Krištuf 2005

Kurtz/Boardmann 1971
B. Arnold: The limits of agency in the analysis of elite Iron Age Celtic burials. Journal of Social Archaeology 1, 2001, 210-224.

B. Benadik: Maňa. Keltisches Gräberfeld. Fundkatalog. Nitra 1983.

J. Brück: Death, Exchange and Reproduction in the British Bronze Age. European Journal of Archaeology 9, 2006, 73-101.

M. Buchvaldek/D. Koutecký: Interpretation des schnurkeramischen Gräberfeldes von Vikletice. Památky Archeologické 63, 1972, 142-179.

J. Bujna: Das laténezeitliche Gräberfeld bei Dubník. II. Analyse und Auswertung. Slovenská archeológia 39, 1991, 221-256.

J. Bujna: Malé Kosihy - latenezeitliches Gräberfeld. Katalog. Nitra 1995.

J. Bujna: Reich ausgestattete Brandgräber mit Holzeinbau auf dem Gräberfeld in Malé Kosihy. Reflexionen und Hypothesen über die Bestattungssitten der Kelten. Slovenská archeológia 46, 1998, 289-308.

J. Bujna: Malé Kosihy. Lexikon zur keltischen Archäologie, L-Z, 2012, 1225-1226. J. Bujna: Maňa. Lexikon zur keltischen Archäologie, L-Z, 2012, 1228-1230.

J. Bujna: Deviantný pohreb na keltskom pohrebisku v Palárikove. Prípadová štúdia nenormatívnych pohrebných praktík. In: J. Čižmářová/N. Venclová/G. Březinová (eds.): Moravské křižovatky. Střední Podunají mezi pravěkem a historií. Brno 2014, 449-458.

J. Chapman: Tensions at funerals. Mortuary archaeology in later Hungarian prehistory. Budapest 2000.

L. Chroustovský: Kontingenční tabulky a vektorová syntéza. Příspěvek k možnostem transformace nominálních dat a jejich následné matematické syntézy. In: J. Macháček (ed.): Počítačová podpora v archeologii 2. Brno 2008, 49-60.

P. Demián: Grave Typology and Chronology of a Lengyel Culture Settlement: Formalized Methods in Archaeological Data Processing. In: J. Kolář/F. Trampota (eds.): Theoretical and Methodological Considerations in Central European Neolithic. Proceedings of the 'Theory and Method in Archaeology of the Neolithic $\left(7^{\text {th }}-3^{\text {rd }}\right.$ millennium BC)' conference held in Mikulov, Czech Republic, $26^{\text {th }}-28^{\text {th }}$ of October 2010. BAR international series. Oxford 2012, 77-93.

Z. Ďudáková: Variabilita spôsobu uloženia keramiky a zvyškov mäsitej stravy v kostrových a žiarových laténskych hroboch z územia juhozápadného Slovenska. In: J. Čižmářová/N. Venclová/G. Březinová (eds.): Moravské křižovatky. Střední Podunají mezi pravěkem a historií. Brno 2014, 487-492.

F. Fahlander: The materiality of serial practice: a microarchaeology of burial. Göteborg 2003.

G. Fusek: Kolokvium Problémy výskumu keramiky v hroboch. Študijné zvesti AÚ SAV 38, 2005, 5.

A. Gramsch: A Microarchaeological Approach to the Social Significance of Late Bronze Age Burial Practices: Age and Gender at the Lusatian Urnfield of Cottbus Alvensleben-Kaserne (Germany). In: P. Cornell/F. Fahlander (eds.): Encounters-Materialities-Confrontations. Archaeologies of social space and interaction. Newcastle 2007, 83-99.

Ø. Hammer: PAleontological STatistics - Reference manual. Oslo 2014.

H. Härke: Grave goods in early medieval burials: messages and meanings. Mortality 19, 2014, 41-60.

A. Kaliff/T. Oestigaard: Cultivating Corpses. A Comparative Approach to Disembodied Mortuary Remains. Current Swedish Archaeology 12, 2004, 83-104.

L. Kaňáková/D. Parma: Štípaná industrie z pohřebiště únětické kultury v poloze Podolí - Příčný (okr. Brno-venkov) jako indikátor sociálních jevů. Archeologické rozhledy 67, 2015, 515-546.

T. Kovářová: The spatial distribution of artefacts in Corded Ware graves. In: L. Šmejda/J. Turek (eds.): Spatial Analysis of Funerary Areas. Plzeň 2004, 21-37.

E. Krekovič: Vel'kost' urny, vek a pohlavie pochovaného na pohrebiskách doby rímskej na juhozápadnom Slovensku. Śtúdijné zvesti AÚ SAV 42, 2007, 113-116.

P. Krištuf: Džbány českého eneolitu. In: E. Neustupný/J. John (eds.): Přispěrky $k$ archeologii 2. Plzeň 2005, 69-118.

D. C. Kurtz/J. Boardmann: Greek Grave Customs. London 1971. 
Müller 2012

Neustupný 2007

Neustupný/Smrž 1989

Oestigaard 1999

Perego 2010

Rebay 2003

Rebay-Salisbury 2007

Reinhold 1996

Repka 2015

Repka 2017

Repka 2018

Rusu-Bolindeț 2014

Shennan 2001

Siklósi 2007

Siklósi 2013

Sørensen/Rebay 2005

Sørensen/Rebay 2008

Styk 2015

Styk 2018

Styk 2019

Trebsche 2011

Valentová/Šumberová 2011

Zeiler 2010
S. Müller: Monumente der Ahnenverehrung? Zur Deutung der hallstattzeitlichen Grabhügel von Nové Košariská. Slovenská archeológia 60, 2012, 343-364.

E. Neustupný: Metoda archeologie. Plzeň 2007.

E. Neustupný/Z. Smrž: Čachovice - pohřebiště kultury se šňůrovou keramikou a zvoncovitých pohárů. Památky archeologické 80, 1989, 282-383.

T. Oestigaard: Cremations as Transformations: When: The Dual Cultural Hypothesis was Cremaed and Carried Away in Urns. European Journal of Archaeology 2, 1999, 345-364.

E. Perego: Magic and Ritual in Iron Age Veneto, Italy. Papers from the Institute of Archaeology 20, 2010, 67-96.

K. C. Rebay: Wein in der Eisenzeit. In: J. Leskovar/G. Schwanzar/G. Winkler (eds.): Worauf wir stehen: Archäologie in Oberösterreich. Linz 2003, 289-297.

K. Rebay-Salisbury: Plotting social change: burial rites, Space and staus at the cemetery of Statzendorf (Austria) In the beginning of the early iron age. In: R. B. Salisbury/D. Keeler (eds.): Space - Archaeology's Final Frontier? An Intercontinental Approach. Newcastle 2007, 134-156.

S. Reinhold: Time versus Ritual - Typological Structures and Mortuary Practices in Late Bronze/Early Iron Age Cemeteries of North-East Caucasia ('Koban Culture'). In: H. Kammermans/K. Fennema (eds.): Interfacting the Past. Computer Applications and Quantitative Methods in Archaeology CAA95. Leiden 1996, 195-202.

D. Repka: Odraz historických udalostí staršej doby laténskej v hrobovej výbave na keltských pohrebiskách v Karpatskej kotline. Reflection of historical events of the early La Tène period (LTB) in the grave inventory on the Celtic burial grounds in the Carpathian Basin. Nitra 2015.

D. Repka: La Tène miniature vessels from the Carpathian Basin. In: J. Kysela/ A. Danielisová/J. Militký (eds.): Stories that made the Iron Age. Studies in Iron Age Archaeology dedicated to Natalie Venclová. Praha 2017, 207-221.

D. Repka: Intentionally broken vessels in Celtic graves. Evidence of funerary rites in the La Tène period. Archeologické rozhledy 70, 2018, 239-259.

V. Rusu-Bolindeț: Pottery in funerary context - Some aspects of conviviality in roman Dacia. Studia Universitatis “Babeş-Bolyai." Historia 59, 2014, 239-284.

S. Shennan: Quantifying archaeology $2^{\text {nd }}$ ed. Edinburgh 2001.

Z. Siklósi: Age and gender differences in Late Neolithic mortuary practice: a case study from Eastern Hungary. In: J. K. Kozłowski/P. Raczky (eds.): The Lengyel, Polgár and related cultures in the Middle/Late Neolithic in Central Europe. Kraków 2007, 185-198.

Z. Siklósi: Traces of social inequality during the Late Neolithic in the eastern Carpathian Basin. Budapest 2013.

M. L. S. Sørensen/K. C. Rebay: Interpreting the body: burial practices at the Middle Bronze Age cemetery at Pitten. Archaeologia Austriaca 89, 2005, 153-175.

M. L. S. Sørensen/K. C. Rebay: From substantial bodies to the substance of bodies: analysis of the transition from inhumation to cremation during the Middle Bronze Age in Central Europe. In: D. Borić/J. Robb (eds.): Past Bodies. Body-Centered Research in Archaeology. Oxford 2008, 59-68.

M. Styk: Lokálne a regionálne rozdiely v pohrebných obradoch a v ríte na laténskych pohrebiskách v strednom Podunajsku. Diplomová práca (Filozofická fakulta UKF). Nitra 2015. Nepublikované.

M. Styk: Metodika analýzy pohrebného rítu. Dizertačná práca (Filozofická fakulta UKF). Nitra 2018. Nepublikované.

M. Styk: Príspevok k metodike analýzy pohrebného rítu. Studia Historica Nitriensia 23, 2019, 169-185.

P. Trebsche: Eisenzeitliche Graphitonkeramik im Mittleren Donauraum. In: K. Schmotz (ed.): Vorträge des 29. Niederbayerischen Archäologentages. Rahden/ Westf. 2011, 449-481.

J. Valentová/R. Šumberová: O pohřebních banketech. Archeologie v stredních Čechách 15, 2011, 435-439.

M. Zeiler: Untersuchungen zur jüngerlatènezeitlichen Keramikchronologie im östlichen Mitteleuropa. Rahden/Westf. 2010. 


\title{
Možnosti priestorovej analýzy keramických prídavkov v hroboch na príklade laténskeho pohrebiska v Malých Kosihách
}

\author{
Matej Styk
}

Súhrn

Výskum keramického inventára prináša nové možnosti v štúdiu pohrebného rítu. Cielom tohto príspevku bolo priniest’ nový pohlad na pomerne starú problematiku. Rôzne možnosti skúmania tvarovej a priestorovej variability hrobovej keramiky prinášajú mnohé technické a interpretačné úskalia. Hlavnou pracovnou metódou bola mikrotopografia prídavkov, ktorá vychádza z myšlienok mikroarcheológie. Správnym technickým nastavením jednotlivých krokov spresňuje pohl'ad na jednotlivé situácie, ktoré sú vždy individuálne riešené. Tieto postupy boli zahrnuté pod širší metodický koncept označený ako Previazaný proces poznania (PPP). Postavenie keramiky v pochovávaní popisoval teoretický model vychádzajúci z variability pohrebného rítu. Oproti "tradičným” prístupom, resp. prístupom striktne rešpektujúcim postup archeologickej metódy, bolo vd’aka PPP možné vykonat’ sériu detailných pozorovaní a hodnotit ich vždy v uzavretom prostredí (hrobu alebo pohrebiska) bez toho, aby sa stratil dostatočný nadhlad. Tým, že bol tento postup odôvodnený predbežným modelom, nemuseli sme sa v interpretačnej rovine držat’ len variability ukladania nádob, ale taktiež priamo hodnotit’ variabilitu pohrebného rítu. Vd’aka tomu bolo možné priamo vytvárat typy, resp. normy pohrebného rítu, neobmedzujúc sa formálnou klasifikáciou (foriem rítu, kategórii hrobov...). Práve tieto dodatočné aspekty, ktoré v prevahe prác figurujú na začiatku analýzy (napr. rozdelenie hrobov na inhumačné a kremačné, alebo podla pohlavia), v sekvencii PPP vstupovali až neskôr, podporujúc tak syntézu štruktúr. Zároveň samotná mikrotopografia nastavená vo vztahu k ludským ostatkom adresnejšie rieši variabilitu keramického inventáru. Spojenie súradnicového systému s morfologickým triedením nádob predstavuje názornú ukážku ako sa vysporiadat’ s technickými problémami formalizovaných postupov. Oproti „tradičným“ prístupom sa zohladnila ako integrita prameňa (základnej jednotky), tak aj kvantitatívna stránka (štruktúry), pričom nedošlo k unáhlenému selektovaniu prameňa a okliešteniu interpretačných možností. Zároveň bola pri analýze variability zohladnená funkcia nádob, ktorá výrazne ovplyvnila dosiahnuté výsledky. Odfiltrovaním intencionálne rozbitej keramiky, pokrievok a urien sme dosiahli cielený súbor, keramický servis. Stanovit’ variabilitu pohrebného rítu môžeme vd’aka tomu už na úrovni štruktúry. Ako bolo v prípadovej štúdii naznačené, k interpretácii je už potrebné jej zapojenie do vyššieho celku, ako napríklad vývoja pochovávania. To v sebe zahrňuje dodatočnú problematiku, častokrát na úrovni komplexu. V predstavenej prípadovej štúdii bolo preukázané, že keramické prídavky vo forme nosičov (keramický servis) sa na pohrebisku v Malých Kosihách vyskytujú v zoskupeniach, ktoré sú typovo a priestorovo exkluzívne pre štyri skupiny pochovaného obyvatel'stva. Dve podobné skupiny bolo možné pozorovat’ aj na pohrebisku v Mani. Z výsledkov vyplýva, že keramické servisy odzrkadlujú určité normy pohrebných praktík a poukazujú na lokálne tradície v pochovávaní. Práve na regionálnej úrovni môžu tieto výsledky lepšie špecifikovat rozdiely v jednotlivých skupinách laténskej kultúry. Práve štúdium regionálnej variability v pochovávaní prinesie hlbšie poznatky o štruktúre laténskej kultúry. K nemu však bude potrebné aplikovat’ uvedené postupy na viaceré pohrebiská z územia JZ Slovenska. Zároveň si treba uvedomit, že variabilita pohrebného rítu pozostáva z viacerých prvkov. Hrobová keramika je len jedným z nich a táto štúdia poukázala na dôležitost’ keramického servisu ako indikátora lokálnych tradícií v pochovávaní. Tie predstavujú spôsob akým minulé spoločenstvá ukladali a aranžovali v priestore hrobu nádoby s funkciu nosičov prídavkov.

Obr. 1. Schéma sekvencie PPP pre riešenie vývoja pochovávania. Šípky - postavenie bodov výskumu v jednotlivých úrovniach PPP; obdížniky - definované oblasti, na ktoré sa zameriavajú metódy analýzy a syntézy.

Obr. 2. Schéma sekvencie PPP pre riešenie priestorového rozloženia keramického inventára. Vychádza z upravenej sekvencie pre vývoj pochovávania so špecifikovanými úkonmi v jednotlivých krokoch.

Obr. 3. Využitie karteziánskej sústavy. Schematické reprezentovanie koordinátov na hrob. 1 - kremačný hrob; 2 - inhumačný hrob.

Obr. 4. Využitie karteziánskej sústavy. 1 - príklad aplikovania sústavy na kremačný hrob 189 (Bujna 1995, obr. 37); 2 - príklad aplikovania sústavy na inhumačný hrob 395 (Bujna 1995, obr. 73b).

Obr. 5. Keramické triedy a ich typy na základe analýzy pohrebiska Malé Kosihy. F1-5 - flaše; M1-3 - misy; T - teriny; $\mathrm{H}$ - hrnce; $\mathrm{V}$ - vázy; $\mathrm{mn}$ - miniatúrne nádoby.

Obr. 6. Výsledný diagram PCA analýzy (príklad 1) keramického inventáru s nedefinovanou funkciou na pohrebisku Malé Kosihy. Jednotlivé entity (hroby) predstavujú výsledky priestorových a morfologických kombinácií keramických prídavkov. Legenda: $\square$-inhumačné hroby; • - kremačné hroby. 
Obr. 7. Výsledný diagram PCA analýzy (príklad 2) keramického inventáru s funkciou nosičov na pohrebisku Malé Kosihy. Jednotlivé entity (hroby) predstavujú výsledky priestorových a morfologických kombinácií keramických prídavkov. Skupina 1 - hroby 9, 62, 95, 109, 235, 335, 356, 470, 477, 506, 526 (príklady podla Bujna 1995, obr. 13b; 19); skupina 2 - hroby 176, 189, 192, 227, 283, 298, 396, 453, 459, 475, 482 (príklady podla Bujna 1995, obr. 37; 46); skupina 3 - hroby 166, 168, 216, 290, 330, 425, 495 (príklady podla Bujna 1995, obr. 28; 42); skupina 4 - hroby 8, 83, 153, 180, 234, 248, 249, 307, 394, 395, 431, 448, 469, 507 (príklady podla Bujna 1995, obr. 73b; 78). Legenda: $\square$ - inhumačné hroby; • - kremačné hroby; sivé - bojovnícke; modré - mužské; oranžové - ženské; zelené - detské; fialové - dvojhroby.

Obr. 8. Výsledný diagram PCA analýzy (príklad 2) keramického inventáru s funkciou nosičov na pohrebisku Maňa. Jednotlivé entity (hroby) predstavujú výsledky priestorových a morfologických kombinácií keramických prídavkov. Zvýraznené sú skupiny zhodné s výsledkami z Malých Kosíh. Skupina 1 - hroby 36, 66, 69, 76, 86, 100, 105, 109, 133, 137, 138 (príklady podla Benadik 1983, obr. 6; 15); skupina 4 - hroby 24, 53, 73, 91, 104, 129 (príklad podla Benadik 1983, obr. 8). Legenda: $\square$ - inhumačné hroby; • - kremačné hroby; čierne - bojovnícke; modré - mužské; oranžové - ženské; zelené - detské; fialové - dvojhroby.

Obr. 9. Pohrebisku v Malých Kosihách. G1-4 - schematické zobrazenie najčastejších kombinácii keramických prídavkov v jednotlivých skupinách. Za prerušovanou čiarou sa nachádzajú alternatívne varianty.

Tabela 1. Základné údaje z pohrebiska Malé Kosihy. 1. čast’ - prvky pohrebného rítu. B. r. - pohrebný rítus (inhumačný/kremačný); Sex - antropologicky určené pohlavie (M - muž, F - žena); Age - antropologicky určený vek (I - infans, J - juvenis, A - adultus, M - maturus); Cat. - sociálna kategória (W - bojovnícke hroby, M - mužské hroby, F - ženské hroby, Ch - detské hroby, D - dvojhroby.); NCI - počet keramických jedincov na hrob. 2. čast’ počet keramických typov. Bot. - flaše; Bow. - misy, P - hrnce; V - vázy; T - teriny; MnV - miniatúrne nádoby; ? - neurčené. 3. čast’ - funkcia keramiky. C - nosič; Rf - rituálna funkcia; Urn - urna; Lid - pokrievka; ? - neurčená funkcia; NSC - počet priestorovo klasifikovaných typov.

Tabela 2. Základné údaje z pohrebiska Maňa. 1. čast’ - prvky pohrebného rítu. B.r. - pohrebný rítus (inhumačný/ kremačný); Sex - antropologicky určené pohlavie (M - muž, F - žena); Age - antropologicky určený vek (I - infans, J - juvenis, A - adultus, M - maturus); Cat. - sociálna kategória (W - bojovnícke hroby, M - mužské hroby, F - ženské hroby, Ch - detské hroby, D - dvojhroby); NCI - počet keramikých jedincov na hrob. 2. čast' - počet keramických typov. Bot. - flaše; Bow. - misy; P - hrnce; V - vázy; T - teriny; MnV - miniatúrne nádoby; ? - neurčené. 3. čast' - funkcia keramiky. C - nosič; Rf - rituálna funkcia; Urn - urna; Lid - pokrievka; ? - neurčená funkcia; NSC - počet priestorovo klasifikovaných typov.

Tabela 3. Nominálne a kardinálne premenné keramických jedincov na pohrebisku v Malých Kosihách. Počet nádob na základe údajov z katalógu (Bujna 1995). Type - typ (-un - neurčený) a funkcia nádob na základe výsledkov analýzy základnej jednotky. Koordináty pre osi x and y. PCA 1 - vstupné dáta pre analýzu príkladu 1; PCA 2 vstupné dáta pre analýzu príkladu 2,f - filtrované dáta. Morf. \& funct. - kombinácia morfologickej ( $\neq$ neurčené) a funkčnej (= nosič) klasifikácie.

Tabela 4. Nominálne a kardinálne premenné keramických jedincov na pohrebisku v Mani. Počet nádob na základe údajov z katalógu (Benadik 1983). Type - typ a funkcia nádob na základe výsledkov analýzy základnej jednotky. Koordináty pre osi x and y. PCA 1 - vstupné dáta pre štatistickú analýzu. Morf. \& funct. - kombinácia morfologickej ( $\neq$ neurčené) a funkčnej (= nosič) klasifikácie.

Mgr. Matej Styk, PhD.

Univerzita Konštantína Filozofa v Nitre

Katedra archeológie FF

Hodžova 1

SK - 94974 Nitra

mstyk@ukf.sk 